\title{
Historical and Technical Notes on Aqueducts from Prehistoric to Medieval Times
}

Giovanni De Feo ${ }^{1, *}$, Andreas N. Angelakis ${ }^{2}$, Georgios P. Antoniou ${ }^{3}$, Fatma El-Gohary ${ }^{4}$, Benoît Haut ${ }^{5}$, Cees W. Passchier ${ }^{6}$ and Xiao Yun Zheng ${ }^{7}$

1 Department of Industrial Engineering, University of Salerno, via Giovanni Paolo II, 132, Fisciano (SA) 84084, Italy

2 Institute of Iraklion, National Foundation for Agricultural Research (N.AG.RE.F.), Iraklion 71307, Greece; E-Mail: info@a-angelakis.gr

3 Technological Educational Institute, Patras, Ioannou Soutsou 44, Athens 11474, Greece; E-Mail: antonioug@tee.gr

4 Water Pollution Research Department, National Research Centre, Bohouth Str. Dokki, Cairo 11787, Egypt; E-Mail: fgohary@hotmail.com

5 Chemical Engineering Unit, Université Libre de Bruxelles, Av. F.D. Roosevelt 50, C.P. 165/67, Brussels 1050, Belgium; E-Mail: bhaut@ulb.ac.be

6 Department of Earth Sciences, Institute of Geosciences, Becherweg 21, Johannes Gutenberg University Mainz, Mainz 55128, Germany; E-Mail: cpasschi@uni-mainz.de

7 International Center for Ecologic Culture Studies \& Department of Academic Affairs Management, Yunnan Academy of Social Sciences, No. 577, Huan Cheng West Road, Kunming 650034, China; E-Mail: zhengxy68@163.com

* Author to whom correspondence should be addressed; E-Mail: g.defeo@unisa.it; Tel.: +39-089-964-113; Fax: +39-089-968-738.

Received: 8 October 2013; in revised form: 15 November 2013 / Accepted: 18 November 2013 / Published: 28 November 2013

Abstract: The aim of this paper is to present the evolution of aqueduct technologies through the millennia, from prehistoric to medieval times. These hydraulic works were used by several civilizations to collect water from springs and to transport it to settlements, sanctuaries and other targets. Several civilizations, in China and the Americas, developed water transport systems independently, and brought these to high levels of sophistication. For the Mediterranean civilizations, one of the salient characteristics of cultural development, since the Minoan Era (ca.3200-1100 BC), is the architectural and hydraulic function of aqueducts used for the water supply in palaces and other settlements. The 
Minoan hydrologists and engineers were aware of some of the basic principles of water sciences and the construction and operation of aqueducts. These technologies were further developed by subsequent civilizations. Advanced aqueducts were constructed by the Hellenes and, especially, by the Romans, who dramatically increased the application scale of these structures, in order to provide the extended quantities of water necessary for the Roman lifestyle of frequent bathing. The ancient practices and techniques were not improved but survived through Byzantine and early medieval times. Later, the Ottomans adapted older techniques, reintroducing large-scale aqueducts to supply their emerging towns with adequate water for religious and social needs. The scientific approach to engineering matters during the Renaissance further improved aqueduct technology. Some of these improvements were apparently also implemented in Ottoman waterworks. Finally the industrial revolution established mechanized techniques in water acquisition. Water is a common need of mankind, and several ancient civilizations developed simple but practical techniques from which we can still learn. Their experience and knowledge could still play an important role for sustainable water supply, presently and in future, both in developed and developing countries.

Keywords: Aqua Claudia; Aqua Marcia; Aspendos; Byzantines; Eupalinos; Gier; Hellenes; Knossos; Nimes; Minoan; Pergamon; Romans; Segovia; Valens

\section{Introduction}

In this paper, the word aqueduct is used for an artificial (man-made) structure (channel, canal, pipeline, inverted siphon, reservoir, and/or tunnel) at the surface or buried, which is constructed to convey water from a water source (surface or underground) to a target (town, villa, sanctuary) for domestic (e.g., fountains, bath houses, and toilets), agricultural, and industrial use (mines, watermills). The main focus of this paper is on surface aqueducts and not on underground ones (tunneling). However, some details are provided on those underground aqueducts, which, in some parts of the world, are named qanats (also foggaras, khettaras, and karez). The scientific evolution of aqueduct construction and aqueduct technologies through the centuries is the main topic of this paper. Aqueduct development worldwide is presented chronologically over 5500 years of human history. Comparative developments of water technologies in several civilizations is reviewed and synthesized. For each of these civilizations, the key elements of engineering practice in aqueduct construction and operation are given.

As aqueduct research and literature focuses heavily on Roman examples (e.g., references in Section 6.8), this paper aims to provide a global balanced perspective extending from the Bronze Age through the Middle Ages. The aqueduct technologies and management practices presented here address problems of collecting, transporting, and distributing of water without modern geodetic equipment, maps, satellite images, pumps, or excavation machinery. The solutions found in ancient time were cost effective and practical techniques, which may assist modern-day aqueduct construction 
and maintenance to be more cost effective, fail-proof, and environmentally friendly, which is particularly, but not exclusively, important in the developing world.

\section{Mesopotamia and Ancient Crete (ca.3300-1100 BC)}

Mesopotamia (Mesopotamos, from mesos "middle" + potamos "river") is the name given by the ancient Hellenes to the land situated between the Euphrates and Tigris Rivers and their tributaries (modern Iraq and parts of modern Syria; Figure 1a). Considering that the origin and development of ideas and techniques are difficult to restrict to a well-defined geographical area because migration, trade and military operations contribute to their diffusion, the term Greater Mesopotamia has been devised, including Western Iran, Eastern Syria, and Southeastern Turkey, as part of the sphere of influence of the land between rivers. Major urban areas in Greater Mesopotamia during the Bronze Age (ca. 3300-1100 BC) are presented in Figure 1b. In these urban centers, water sources included canals connected to rivers, rainwater harvesting systems, wells, aqueducts, and underground cisterns.

Figure 1. Major urban areas in Greater Mesopotamia: (a) General view [3]; and (b) Tigris and Euphrates Rivers with the major cities during Bronze Age [4].

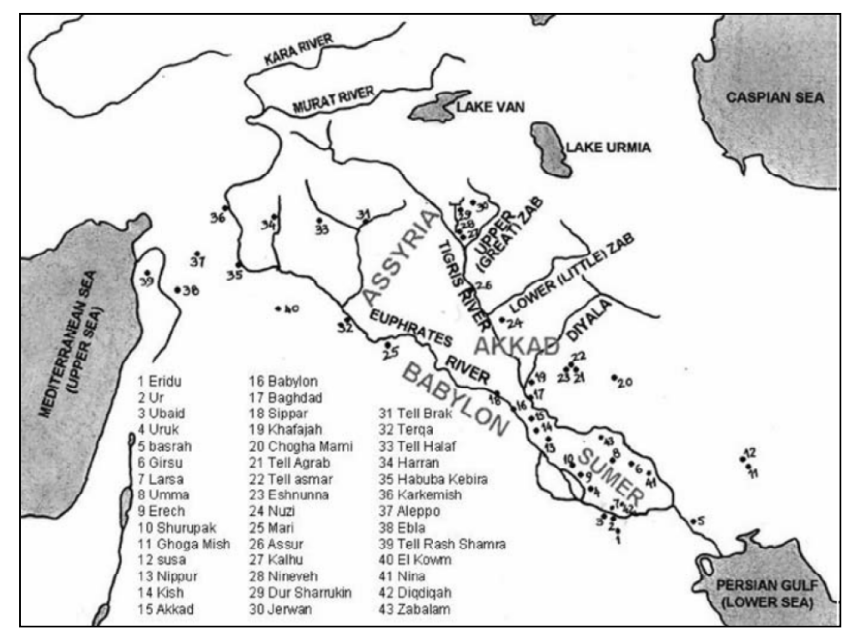

(a)

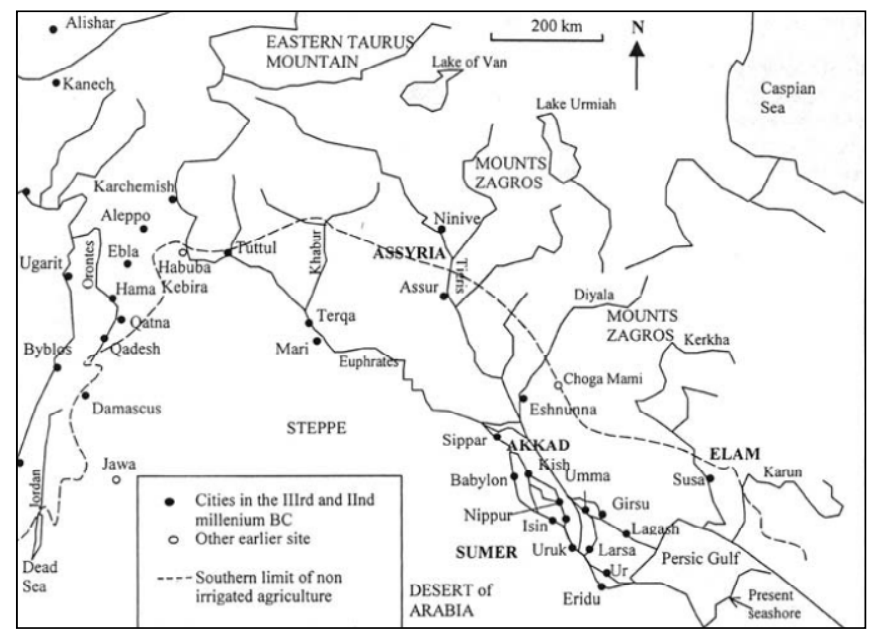

(b)

In Mesopotamia, during the development of the Bronze Age urban centers of the Sumer (Sumerian) and Akkud ( $c a$. 3rd millenium BC) Civilizations, a canal connected civilization centers to the Euphrates River and its tributaries for both navigation and water supply. In Mari, a canal led to and passed through the city [3,4]. Servants filled a $25 \mathrm{~m}^{3}$ cistern with water supplied by the canal. Additional cisterns were subsequently built in Mari, connected to an extended rainfall collection system. Terracotta pipes were used in Habuba Kebira (in modern Syria), a Sumerian settlement in the middle Euphrates valley, $c a$. in the middle of the 4th millennium BC $[3,4]$.

In Ancient Crete, the technology of transporting water by aqueduct to palaces and other settlements was well developed as early as the Early Minoan Era (ca. 3000 BC). Frequent earthquakes may locally have caused a decline of aquifer levels and made it necessary to transport water from longer distances [5,6]. In the Minoan palace of Knossos, terracotta pipes for water distribution have been found, suggesting the existence of an aqueduct. Similar terracotta pipes have been found in other 
Minoan settlements such as Tilissos, Gournia, and Vathypetro, as well as in the Caravanserai, located to the south of Knossos palace [5,6]. Water was transported by closed or open terracotta pipes and/or open or covered channels of various dimensions and sections. Water sources for some urban centers in Mesopotamia and Ancient Crete during the Bronze Age are summarized in Table 1. In addition the characteristics of the major Minoan aqueducts are referenced in Table 2.

Table 1. Summary of sources of water for cities, settlements, and palaces in Mesopotamia and Ancient Crete during the Bronze Age (3300-1100 BC) (adapted from Viollet [4]; Tamburrino [3]).

\begin{tabular}{cc}
\hline Source of water & Cities, settlements or palaces \\
\hline Short canal connected to permanent river & Uruk, Ur, Babylon (cities in the Tigris andEuphrates valleys) \\
Canals and reservoirs storing flood water of & Khirbet el Umbashi (Syria) \\
non-permanent river, rainfall & Aghia Triada, Chamaizi, Knossos, Myrtos Pygros, Phaistos, and \\
Rainwater harvesting (gutters and cisterns) & Zakros (Crete) \\
Wells & Ugarit (Syria) \\
Aqueducts from source at altitude & Knossos, Mallia, and Tylissos (Crete), Chogha Zanbil (Iran) \\
Underground cisterns & Zakros and Tylissos (Crete) \\
Springs & Knossos and Tylissos (Crete) \\
\hline
\end{tabular}

Table 2. Characteristics of major aqueducts in Minoan Crete (adapted from Angelakis and Spyridakis [6]).

\begin{tabular}{ccccc}
\hline Aqueduct name & Location & Construction & Reconstruction & Length (km) \\
\hline Gournia & Faneromeni, Asari & Minoan & - & 7 \\
Karphi & Karphi, Lassithi & Minoan & - & not available \\
Knossos (Mavrokolympos) & Knossos & Minoan & Roman & 0.7 \\
Malia & Profitis Ilias, Malia & Minoan & Hellenistic, Roman & 0.85 or 1.15 \\
Mochlos & Mochlos, Lassithi & Minoan & - & 3 \\
Tylissos & Tylissos & Minoan & - & 1.4 \\
\hline
\end{tabular}

The advanced water distribution systems of Minoan palaces and cities merit study since there is no archaeological evidence of aqueducts in Hellas prior to the Minoan Era. Additional evidence suggests that Minoans developed this technology locally [6]. Thereafter, aqueducts were used by the Mycenaeans in continental Hellas.

\section{Ancient Egypt (ca. 3000-67 BC)}

With regard to environmental pollution and human health, Nriagu [7] argues that the development of sustainable water management in ancient Egypt enabled its population to live in harmony with the natural flood cycle of the Nile.

The ancient Egyptians began practicing some form of water management for agriculture about 5000 years ago [8]. With the irrigation of the Nile, they developed lift irrigation with the shaduf, a large pole balanced on a crossbeam, a rope and bucket on one end, and a heavy counter weight at the other, the Archimedes' screw (or tanbur), and the waterwheel (or saqiya) [8]. Ancient Egyptian 
hydraulic engineering is renowned for the construction of a navigable channel linking the Red Sea and the Nile delta. They developed river ports along the Nile, e.g., Memphis and Thebes. Typical landing facilities included simple ramps or docks on wooden or stone piles. The only vestiges of a seaport ( $c a .1900$ BC) were discovered on the Red Sea coast at the mouth of Wadi Gasus [9].

The construction of gravity-fed aqueducts was not possible in Ancient Egypt, as water resources at elevation were not available [10]. As an exception, Achaemenid Persians used a qanat to supply water to the Kharga Oasis (located in the Libyan Desert, about $200 \mathrm{~km}$ to the west of the Nile valley) by about $525 \mathrm{BC}$ [11]. A qanat is constructed as a series of well-like vertical shafts, connected by a gently sloping tunnel (see Figure 2). A qanat taps into subterranean water in a manner that efficiently delivers large quantities of water to the surface without the need for pumping: The water drains by gravity, typically from an upland aquifer. The main difference between an aqueduct tunnel and a qanat is that a qanat is entirely a water collecting system dug at or below groundwater level while an aqueduct tunnel mainly transports water captured elsewhere [12]. Qanats can be up to $18 \mathrm{~km}$ long [13]. Qanats are commonly excavated close to their destination, usually for agricultural irrigation and/or for domestic water supply. The construction techniques of the qanats have remained almost unchanged for 2000 years: The process begins with the digging of the vertical shafts, which are then linked by the underground canal [14].

Figure 2. Cross section of a typical qanat (image from the Wikimedia Commons, author: Samuel Bailey).

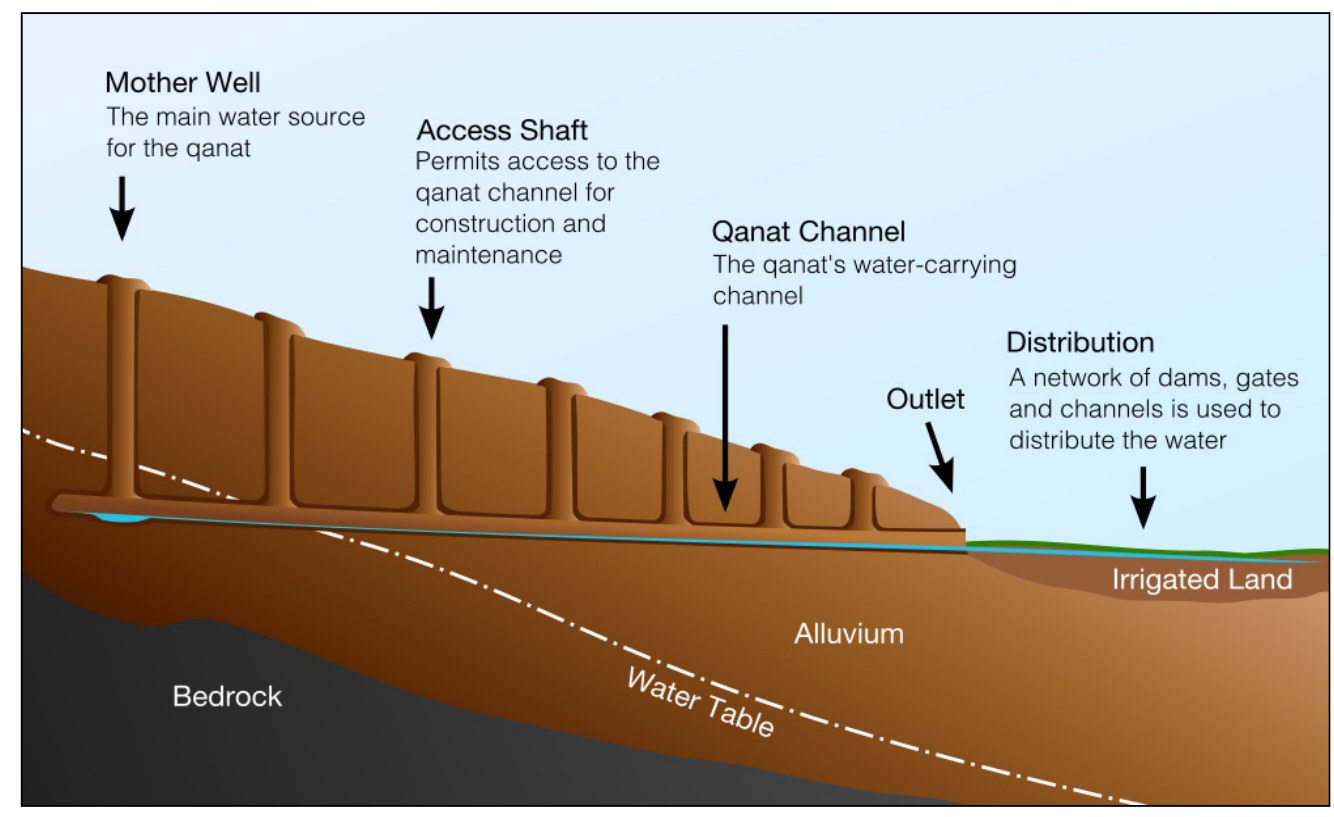

\section{Indus Valley Civilization (ca. 2600-1900 BC)}

The Indus Valley Civilization that developed along the banks of the Indus River, constructed extensive subterranean urban plumbing systems including drains and water pipes feeding baths. Each house also had its own plumbing [15]. Due to the significant year-to-year variation in the duration and intensity of the monsoon, the region experienced frequent climatic extremes, with alternation of floods 
and droughts, which caused pronounced temporal variations in water supply and necessitated large hydrological schemes, including works of irrigation and water conservation, river control, and drainage [7].

Harappa (near Punjab, Pakistan) and Mohenjo-Daro (in the province of Sindh, Pakistan) were the major cities (35-40,000 inhabitants) of the Indus Civilization, but there were also about 300 smaller settlements along the Indus River. Mohenjo-Daro, built around $2450 \mathrm{BC}$ in a semi-arid environment, was serviced by at least 700 wells, with an average frequency of one in every third house [8,16]. The earliest evidence of settlement along the upper Indus River dates to $c a .3300 \mathrm{BC}$ when a small village developed at Harappa. Between ca. 2800-2600 BC, Harappa grew from a small town to a major city (approximately 150 ha in $2600 \mathrm{BC}$ ). In approximately $1900 \mathrm{BC}$, Harappa's infrastructure began to deteriorate, although the city was not abandoned until possibly as late as $1300 \mathrm{BC}$ [17].

\section{Pre-Columbian Cultures (ca. 2600 BC-Early 16th Century AD)}

The Maya civilization ( $c a .1000$ BC-1000 AD) extensively modified the landscapes of the southern lowlands of Mexico to provide irrigation for agriculture [18]. The Maya people constructed aqueducts and causeways that channelized and diverted water around, away from, and under their sites from the Guatemalan Highlands to Copán, Honduras and to Palenque, Mexico [19].

At Palenque, one of the best-known Mayan centers, the Maya people developed a sophisticated technology for the transport of water under pressure. The method recalls that used by the ancient Hellenes and Romans. Arguably, the Maya people of Palenque had empirical knowledge of closed-channel water pressure [20]. Kirk and Duffy [20] state that other examples of pre-Columbian water pressure technology probably exist throughout the Americas. One of these examples could be the segmented ceramic tubing discovered at several sites throughout central Mexico. These ceramic pipes are tapered, with each segment fitting into the wide end of the next, and cemented tightly together.

In Oaxaca (Mexico), the Maya people built aqueducts and canals that efficiently irrigated the majority of the valley. In contrast, contemporary water control systems generally irrigate only parts of the same area for agriculture, but leave major sectors of land dry and unusable [21].

Mesoamerican and South American cultures in pre-Columbian times interacted in Costa Rica. One of the most significant archaeological sites in Costa Rica, presently known as Guayabo, is located on the slopes of the Turrialba volcano. The site includes aqueducts built with lava boulders, flagstones and water-rounded river cobbles (mostly lava rocks) [22].

During the 4500 years of South American pre-Columbian history, numerous civilizations emerged, mainly in the western coast and the Andean regions of South America, e.g., the Chavín, the Moche, the Nazca, and the Huari. Around 1530 AD, almost all of their former territories, people and knowledge formed part of the Inca Empire. This pre-Hispanic state featured the largest extension in America, with a population of about 15 million inhabitants of different cultures and languages, including territories along the coast and the Andes of Peru, Bolivia, Ecuador, Colombia, Chile, and Argentina. The Incas, who existed as an empire for approximately 100 years before the arrival of the Spanish, conquered or annexed almost every contemporary civilization in the Andes and adjacent coastal regions, and assimilated all knowledge they encountered, including hydraulic engineering technologies [23].

The Cumbe Mayo archaeological site located near the Peruvian city of Cajamarca, features the ruins of a $9 \mathrm{~km}$ long Pre-Incan aqueduct, built around 1500 BC [24]. The aqueduct collected water from the 
Atlantic watershed and redirected it on its way to the Pacific Ocean. The channel was excavated in volcanic rock and is 35 to $50 \mathrm{~cm}$ wide and 30 to $65 \mathrm{~cm}$ deep (Figure 3). Locally the channel follows a zigzag course, possibly to diminish flow speed and prevent erosion. Arguably, in order to be able to design and build a channel with such a precision, the master builder must have employed some levelling instrument.

Figure 3. Cumbe Mayo aqueduct (image in the public domain).

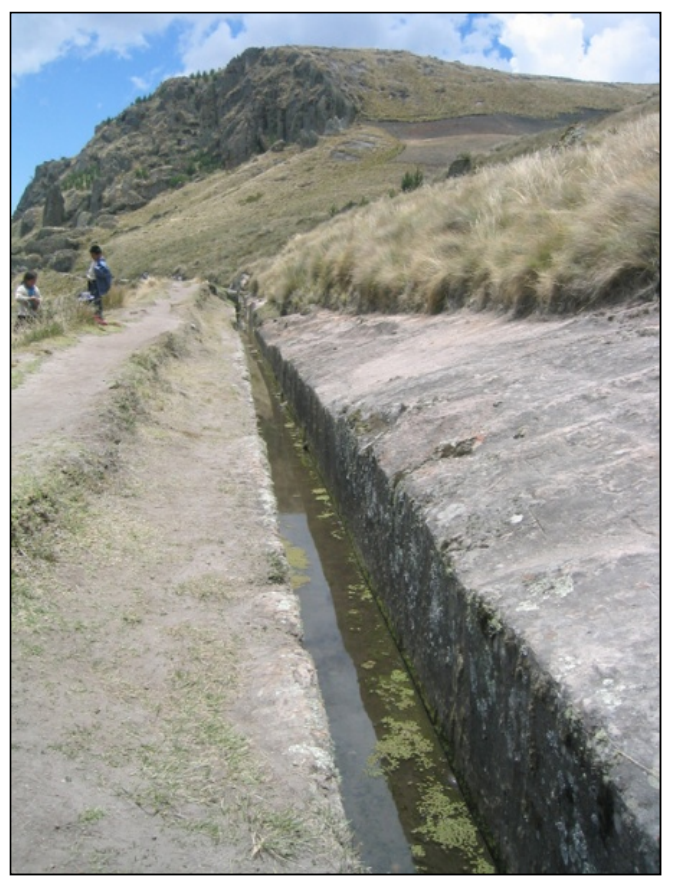

The Nazca culture flourished from $c a$. 100 BC to 800 AD along the dry southern coast of Peru. Nazca people constructed underground galleries (puquios) covered with stones, flagstones, and/or Huarango-tree trunks to collect and conduct underground water to the arid zones of the Aja, Tierras Blancas, and Nazca valleys. Openings permitted access into the deeper underground galleries for maintenance and cleaning operations by means of spiral-formed descending ramps. The distance between the openings varied from 10 or $20 \mathrm{~m}$ to about $180 \mathrm{~m}$. The length of these underground galleries varies from about 500 to $1500 \mathrm{~m}$, at depths of approximately 10 to $20 \mathrm{~m}$ below ground. The galleries were quite narrow with an average cross section of approximately one square meter. The water arrived in reservoirs (cochas) from which the water was distributed via open irrigation channels mainly for agricultural purposes [23].

Between ca. 300-1100 AD, people of the Wari (central highlands of Peru) and Tiwanaku (Western Bolivia) Empires built extensive irrigation canals and agricultural terracing to create a large artificial agricultural landscape in order to serve their growing populations [18].

The Inca Civilization had cities of up to 200,000 people, supplied with water from aqueducts originating in forests located in the Andes Mountains [18]. Springs, fountains and rivers played an important role in Inca architecture and religious beliefs. The ability to store and distribute goods, including water, contributed to the Inca's ability to maintain an empire [25].

In the archaeological site of Tambomachay, near Cuzco, in the southern Peruvian highlands, water was discharged from a small opening (approximately 0.2 by $0.3 \mathrm{~m}$ ) in the main retaining wall to a 
channel along the base of the wall. This channel in turn empties to another stone lined channel that crosses the terrace and feeds a single as well as a double fountain [25].

\section{Historical Times}

\subsection{Chinese Dynasties and Empires (ca. 770 BC-1911 AD)}

The history of aqueducts in China can be traced to $c a .3000$ years ago. Historical and archaeological evidences illustrate that early civilizations in China emerged along the middle basin of the Yellow River. Because of the unbalanced water distribution of the Loess Plateau, the natural water availability for developing agriculture and cities became insufficient around $c a .770 \mathrm{BC}$. This was the golden age of early urbanization in Chinese history, when many small kingdoms emerged, catalysing population growth and urban constructions. Consequently, increased water supply was required in both urban and rural areas. Although the early history of aqueducts in China was mainly associated with agricultural irrigation, the development of a united state (Qin Empire) precipitated the development of large cities and aqueduct construction for urban water supply. Most aqueducts in China consist of simply designed, wide, open canal systems.

Historical records document that many aqueducts were built for developing irrigation around 600 BC. For example, the Zhi Boqu aqueduct, the Yin Zhang Shi Er Qu aqueduct, and the Bai Qi Qu aqueduct in Shanxi, Hebai, Hubai province, are tens of kilometres long. Some of these aqueducts continue to function today [26].

The most typical aqueduct from this age is the Zheng Guo Qu aqueduct (Figure 4). Its construction started in $246 \mathrm{BC}$ and finished about ten years later. The aqueduct was about $300 \mathrm{~km}$ long and was built to bring water from the Jin River to irrigate the area of the Guan Chong plateau. In 95 BC, another aqueduct, named Bai Gong Qu, was built. It was approximately $200 \mathrm{~km}$ long and its purpose was to bring more water from the Jin River to the area of the Guan Chong plateau. This aqueduct was connected with the ZhengGuo Qu aqueduct and, consequently, both aqueducts are commonly collectively named the Zheng Bai Qu aqueduct. Both brought prosperity to the Guan Chong plains for over 2000 years.

Figure 4. Zheng Guo Qi aqueduct.

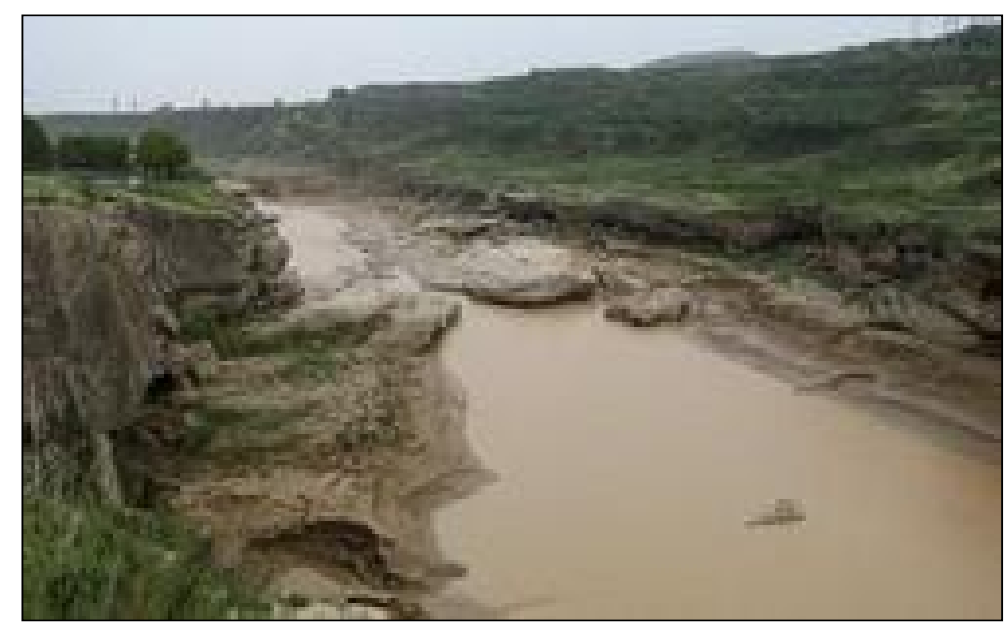


Beijing was the capital during three dynasties (Yuan, Ming and Qing, 1271 to 1911 AD) and featured a system of aqueducts. In the Yuan dynasty, a reservoir, named Kunming Lake (area of 130 ha in the 1930s), was built to the west of Beijing as a water resource for the city. After the construction of the reservoir, three aqueducts were built to transport water from the Nanchang River into the city. These aqueducts increased the water supply of the palaces as well as the resident areas and continue to function today.

In Kunming city, the capital of the Yunnan province, two early ca. 12th century AD aqueducts were constructed. They were called the Jing Zhi He River (35 km long) and the Yin Zhi He River (17.6 km long). These aqueducts played an important role in the city water management for over a thousand years (Figure 5). Prior to their construction, the only river to supply the city was the Pan Long Jaing River, which flooded frequently in summer but provided insufficient water for irrigation for the countryside near the city, especially in winter. After the new aqueducts were built, flooding was mitigated and irrigation for large areas of farmland was provided [27].

Figure 5. A current part of the Jing Zhi He River.

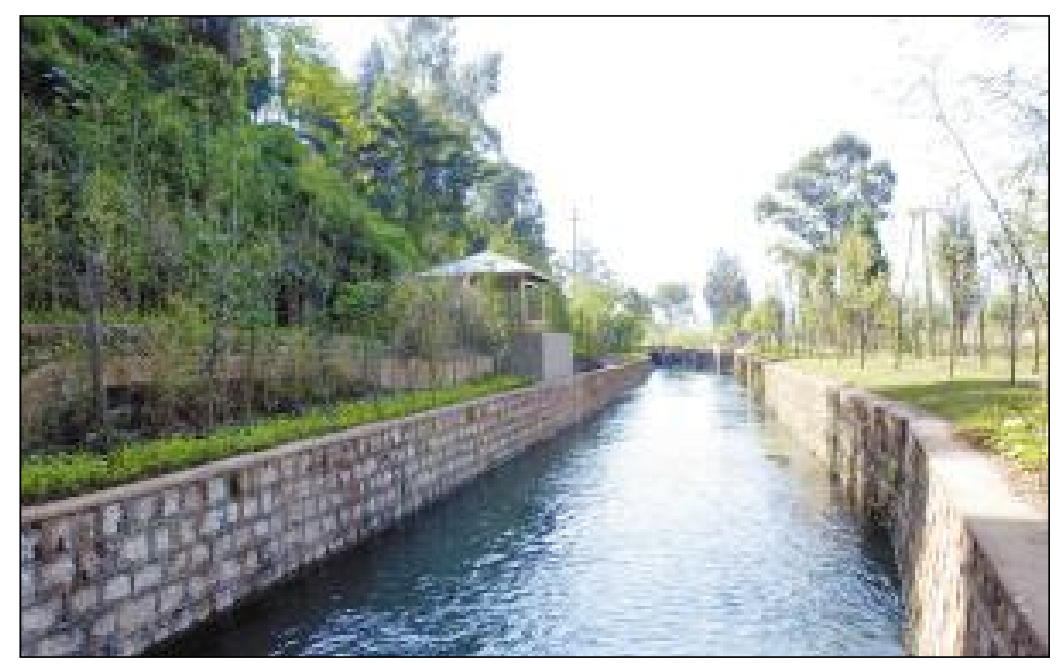

Qanats are also found in China, in the Xinjaing Uygur Autonomous Region (Western China) (Figure 6). Though the provenance and initial construction of qanats in this area of China remains a subject of scholarly debate, scholars agree that the qanats greatly contributed to the agricultural and domestic prosperity of local residents. In the 1950s, around 1600 qanats (40 to $60 \mathrm{~km}$ long) existed in XinJaing, delivering water from the mountains to the villages, towns and the farmlands.

\subsection{Hittite Empire (ca. 1700-1180 BC)}

The Hittite Empire constructed collection ponds and dams to serve urban centers. In the capital Hattusa (near modern Boğazkale, Turkey), two large ponds $\left(36,000\right.$ and 20,000 $\mathrm{m}^{3}$ ) were fed by groundwater and served to supply water to the city [28]. Other important dams were located at Alacahoyuk, with a water source inside the reservoir: The Eflatunpınar dam near Beyşehir, the Golpınar Dam near Corum, the Koylutolu dam near Ilgin, and a sping chamber in Boğazköy [29,30]. The aqueducts fed by the dams typically consisted of lines of conical ceramic pipes (0.6-0.9 $\mathrm{m}$ long and $11-22 \mathrm{~cm}$ in diameter) [30]. 
Figure 6. Qanat in XinJaing.

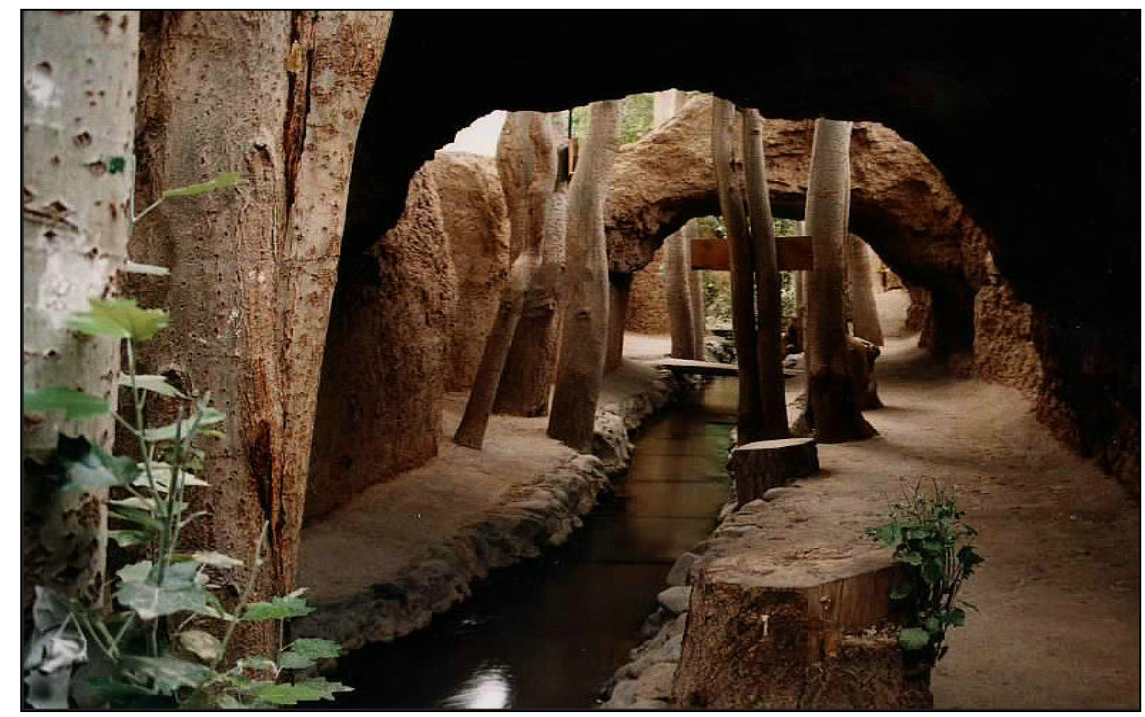

\subsection{Urartu Kingdom (ca. 1000-700 BC)}

The Urartu Kingdom, on the shores of Lake Van in Eastern Anatolia, produced waterworks including the Menua and Ferhat aqueducts. The Menua aqueduct (56 km long) was constructed in $c a$. $800 \mathrm{BC}$ and had a capacity of 2 to $3 \mathrm{~m}^{3} / \mathrm{s}[31,32]$. It is 3-4 m wide with a 1.5-2.0 m deep open channel, which is supported by retaining walls of up to $12 \mathrm{~m}$ tall and was partly carved out of bedrock [33]. The Ferhat aqueduct was also excavated out of bedrock but had a smaller capacity [30]. The Urartian capital, Rusahinili, was supplied by the Rusa Lake, which was enlarged by the construction of two dams $[29,30]$.

\subsection{Persian Empire (550-331 BC)}

Qanats were arguably first invented $c a$. in the 7th century BC in what is now Iran, and the technique spread widely during the Persian Empire between 550 and 331 BC. The qanat technique was exported to China, Central Asia, and the Middle East. Qanats were employed by the Romans and Byzantines in Syria and Jordan [34], and are still in use throughout central Asia. In Iran, 22,000 qanats have been documented [13].

\subsection{Etruscan Civilization (ca. 800-100 BC)}

The Etruscans constructed aqueducts tunnels that were similar to qanats. Their development was the basis for agricultural innovation that fuelled the expansion of the Etruscan civilization [35].

Remains of Etruscan aqueducts have been found in several central Italian cities. In Marzabotto, in the Province of Bologna, an Etruscan aqueduct was excavated between 1870-1872 AD. The main channel was located at a depth of approximately $4.50 \mathrm{~m}$; its inner dimensions are $1.45 \mathrm{~m} \times 0.65 \mathrm{~m}$ [36].

The Etruscan town of Veio, a few kilometres from Rome, featured a complex network of underground aqueducts, $50 \mathrm{~km}$ of which still remain, all built between $c a$. the 9th and 5th century BC. The aqueducts functioned to drain rainwater during floods, and to precisely manage the distribution 
of water during droughts through a system of floodgates, tunnels, barrages, artificial lakes, and wells [36,37].

In the Etruscan city of Cerveteri (Kaisra), in the Province of Rome, founded approximately in the 8th century BC, there are 1550 m of galleries, with 23 manhole shafts (lumina), each with an average depth of $20 \mathrm{~m}$. The aqueducts are arguably Etruscan, but were repaired during the Augustan Age [38].

In the municipality of Tuscania, in the province of Viterbo, Lazio region, there is a dense network of about 70 hypogean tunnels that still feed local fountains [35]. In the same province, in the Etruscan necropolis of Tarquinia, beneath the Doganaccia Tumulus, an underground conduit was dug in volcanic rocks with a steep slope, probably having a drainage function.

In the city of Chiusi, in the Tuscany region of Central Italy, one of the main cities in the league of the twelve Etruscan cities that ruled between the $c a$. 7th and 5th centuries BC, there is an Etruscan aqueduct, consisting of tunnels at different levels and of different dimensions, about $1 \mathrm{~m}$ wide and $2.5 \mathrm{~m}$ high.

\subsection{The Classical and Hellenistic Periods (ca. 480-67 BC)}

Historical and archaeological evidences show that the Minoan aqueduct technology was further developed and spread all over Hellas during the archaic (ca. 750-500 BC) and classical (ca. 500-336 BC) periods. The advancement of aqueduct technology and water management is illustrated by the extraordinary example of the water supply of the Aegean island of Samos, which was admired in antiquity and remains so today [39]. The system featured the Eupalinean digging, also known as the tunnel of Eupalinos, named after the engineer from Megara who designed and constructed it. The total length of the aqueduct exceeds $2800 \mathrm{~m}$, with a $1036 \mathrm{~m}$ long section within the tunnel of Eupalinos (see Figure 7). Its construction began in $530 \mathrm{BC}$, during the tyranny of Polycrates, and it took ten years to complete. It remained in operation until the $c a$. 5th century AD.

Figure 7. A view of the tunnel of Eupalinos with the aqueduct channel on the right hand side of the picture (below the fence).

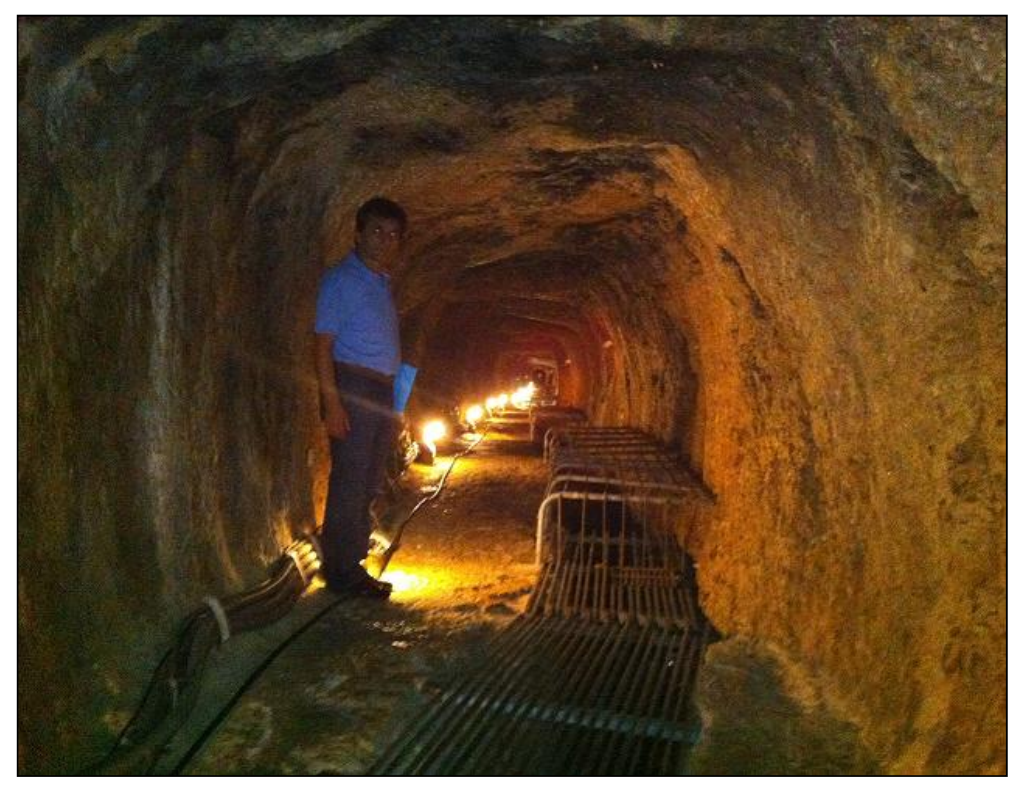


Another aqueduct of similar technology was discovered on the Aegean island of Naxos. The original phase of this aqueduct construction is dated to the late $c a$. 6th century $\mathrm{BC}$, either during the tyranny of Lygdamis or during a succeeding brief interval of democracy on the island. The aqueduct was $11 \mathrm{~km}$ long, ran along the hillside at the upper limit of the agricultural land, and consisted of socket-jointed clay pipes with a diameter of about $0.30 \mathrm{~m}$, buried in a ditch about $1 \mathrm{~m}$ deep. Its slope varied from $1 \%$ to $4 \%$ [40].

In the $c a$. 6th century $\mathrm{BC}$, under the tyranny of Peisistratos (who seized the power in $546 \mathrm{BC}$ and ruled until his death in $527 \mathrm{BC}$ ) and later under his sons, large public works were carried out in the city of Athens. One aqueduct, named after Peisistratos, carried water from the foothills of the Hymettos Mountain, to the center of the city near the Acropolis [39].

Sections of that underground aqueduct, partly built in a qanat-fashion, collect nowadays water for the irrigation of the National Gardens. An ancient aqueduct also existed in Chalkis, which incorporated channels cut in the rock, reused centuries later by the Ottomans [41,42]. Late, but notable Hellenistic aqueducts include those of Pergamon. Originally, the water needs of the city were met by rainwater stored in a system of cisterns. Around 200 BC, as the city began to expand, water demand exceeded the locally available amount. Three aqueducts were installed to carry water from the mountains to the city. One aqueduct, carrying water from the Madradag Mountain, crossed the depression to the north of the city hill by an inverted siphon more than $3 \mathrm{~km}$ long with a maximum pressure head of about $180 \mathrm{~m}$. This inverted siphon was fabricated of lead pipes anchored with large stone constructions [39]. A sediment-settling chamber was built at the upstream end of the inverted siphon to prevent it from obstruction by sediments [43]. The great length of the construction and, above all, the high-pressure head, both of which made alternatives unfeasible, is a milestone of hydraulic engineering. Characteristics of major Classical and Hellenistic aqueducts are referenced in Table 3.

Table 3. Characteristics of Classical and Hellenistic aqueducts (adapted from De Feo et al. [44]).

\begin{tabular}{|c|c|c|c|c|c|}
\hline Aqueduct name & Location & Period & Age of construction & $\begin{array}{c}\text { Length } \\
(\mathbf{k m})\end{array}$ & $\begin{array}{l}\text { Flow rate } \\
\left(\mathbf{m}^{3} \mathbf{d}^{-1}\right)\end{array}$ \\
\hline Naxos & Naxos, Greece & Classical & 6th century $\mathrm{BC}$ & 11.0 & - \\
\hline $\begin{array}{l}\text { Peisistratean (terracotta pipes in shallow } \\
\text { trench, qanat-fashion) }\end{array}$ & Athens, Greece & Classical & Late 6 th century $\mathrm{BC}$ & - & - \\
\hline Eupalinos & Samos, Greece & Classical & $530-520 \mathrm{BC}$ & 28 & - \\
\hline $\begin{array}{l}\text { Hymettos (tunnel and wells up to } \\
14 \mathrm{~m} \text { deep, qanat-fashion) }\end{array}$ & Athens, Greece & Classical & $\begin{array}{r}\text { Late } 5 \text { th or early } \\
4 \text { th century BC }\end{array}$ & 6.5 & \\
\hline $\begin{array}{l}\text { Acharnian (elliptical terracotta tubes in } \\
\text { shallow trench, qanat-fashion) }\end{array}$ & Athens, Greece & Classical & Early 4 th century BC & 19.5 & \\
\hline $\begin{array}{l}\text { Long Walls aqueduct (shallow tunnel } \\
\text { and wells, qanat-fashion) }\end{array}$ & Athens, Greece & Unknown & Unknown & $\sim 9$ & \\
\hline Paggaio Mountain 1 & Greece & Classical & 4th century BC & 14 & - \\
\hline Paggaio Mountain 2 (qanat-fashion) & Greece & Classical & 4th century BC & 20 & - \\
\hline Polyrrhenia 1 (qanat-fashion) & Polyrrhenia, Crete & Classical & 4th century BC & & \\
\hline Polyrrhenia 2 (qanat-fashion) & Polyrrhenia, Crete & Classical & 4th century BC & & \\
\hline Attalos & Turkey & Hellenistic & - & 15 & - \\
\hline Demophon & Turkey & Hellenistic & - & - & 1,500 \\
\hline Madradag & Pergamon, Turkey & Hellenistic & 200-190 BC & 50 & 40,000 \\
\hline
\end{tabular}




\subsection{Nabataean and Hasmonean Aqueducts}

In Israel and Jordan, a large number of aqueducts supplied towns and fortresses in the desert with water. Although relatively small structures, aqueducts that served Nabataean cities in Jordan, such as Petra and Humeima, testify to the great expertise of Nabataean architects [45]. Aqueducts tapped the small springs and transport water over several kilometers to the cities in channels that are usually less than $15 \mathrm{~cm}$ wide (see Figure 8). These were excavated in bedrock or laid out as long sections of covered, hollowed U-shaped blocks, meant to preserve as much water as possible from evaporation. It is worth mentioning that the hydraulic works at Petra served also to mitigate the risk from floods [46]. In Israel, the Hasmonean palaces and fortresses were supplied by aqueducts that transported water from springs. Some aqueducts only operated in times of flood, and fed large cisterns that only stored water occasionally [47]. The aqueducts and cisterns of Masada are a well-known example of this.

Figure 8. Aqueduct located in the Siq, the narrow entrance to the Nabataean city of Petra.

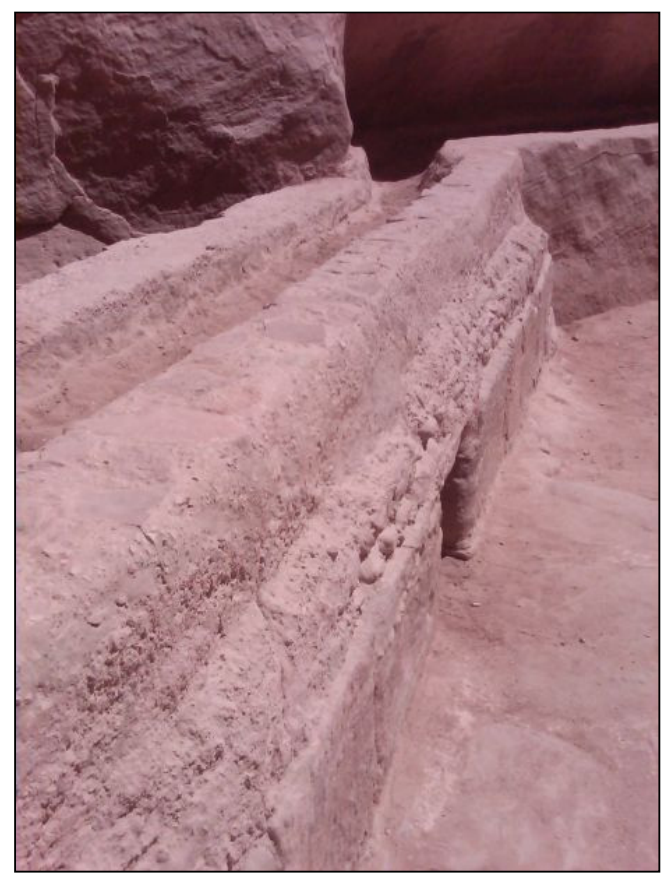

\subsection{Roman Period}

Aqueduct construction in the Mediterranean reached an apex in the Roman Imperial Age (ca. 50-300 AD), when hundreds of them were built in a time of great economic prosperity [48]. Roman aqueducts are found from Scotland to Iraq, and from the foot of the Kaukasus to the northern edge of the Sahara desert (Figure 9). Roman aqueducts were arguably more common, larger in size and capable of transporting a greater water volume than their Minoan, Etruscan, and Hellene predecessors. The construction of public baths demanded large volumes of running water. Daily consumptions between 200 and 500 liters per inhabitant are reported [49-51]. Nearly all aqueducts provided water for public baths and drinking water fountains, although industrial and irrigation applications are also known. The most spectacular industrial application is for gold mining (Dolaucothi, Las Medullas, Tres Minas). The Las Medulas gold mining site in Spain was served by at least eight long aqueduct 
channels with a combined length close to $600 \mathrm{~km}$ [52]. The Tres Minas site, in Portugal, was served by seven aqueducts with a combined length of over $230 \mathrm{~km}$.

Figure 9. Location of the presently known major Roman aqueducts present in the ROMAQ Database (it is a project that aims to localize and collect all publications on ancient aqueducts within the borders of the Roman Empire, focusing on roman aqueducts built in the period $400 \mathrm{BC}$ to $400 \mathrm{AD})$ [48].

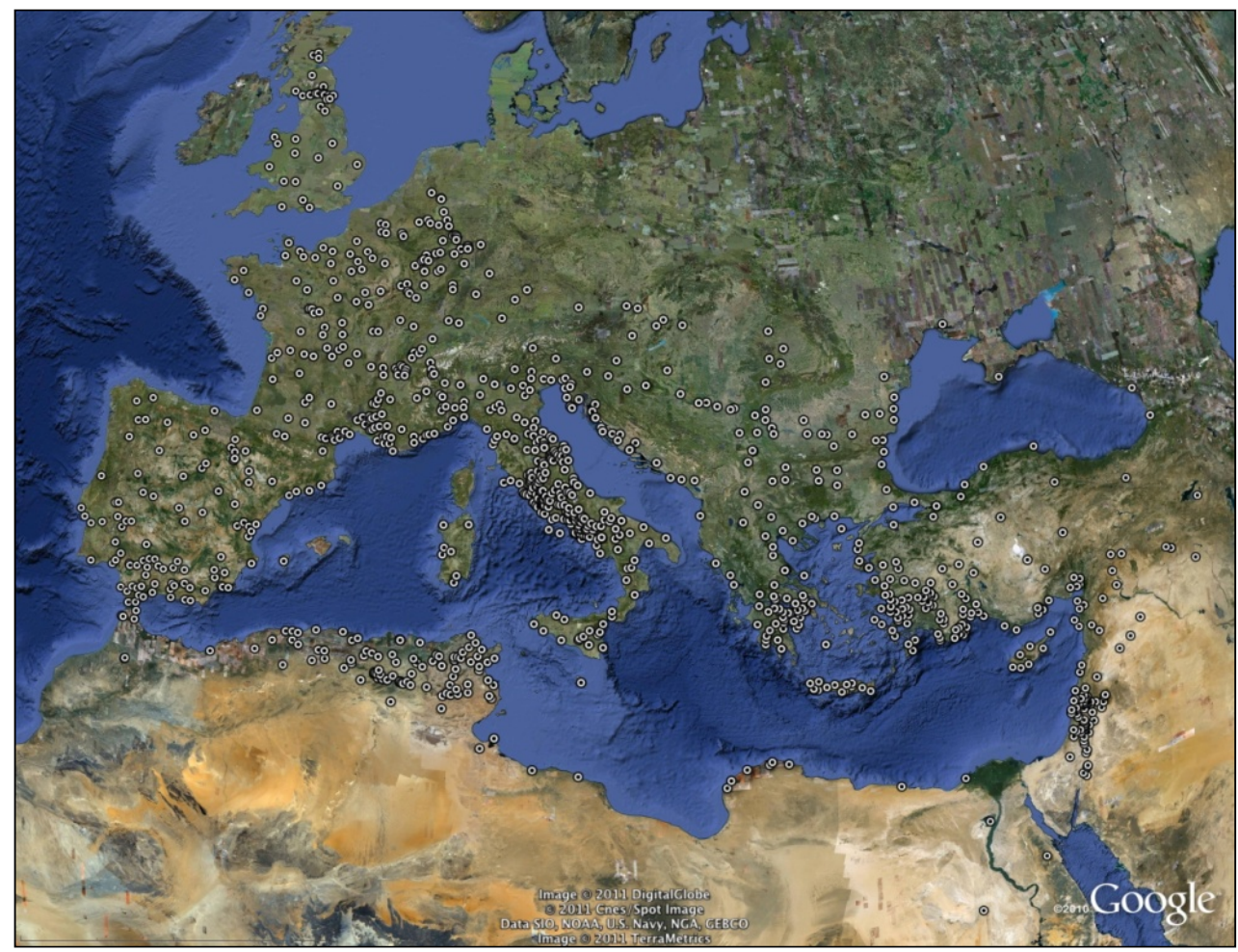

Most aqueducts were fed by karstic springs in limestone areas (e.g., the aqueducts of Carthage in Tunisia, Nîmes and Fréjus in France, Side and Patara in Turkey) or by galleries that tapped an aquifer directly (e.g., the aqueducts of Windisch in Switzerland, Almunecar in Spain, Cologne in Germany), but some were fed by rivers (e.g., the aqueducts Trier in Germany, Segovia in Spain). Aqueducts were also fed with dams (e.g., the aqueduct in Merida, in Spain, the Anio Novus aqueduct of Rome) or weirs (low thresholds in rivers over which water was flowing) (e.g., the aqueducts in Trier and Segovia), but this was less common.

Roman aqueducts were usually built as buried masonry channels with a rectangular internal profile and a semi-circular vault [50,53] (Figure 10). The larger channels are usually high enough for workers to enter the channel and pass through it for inspection and maintenance. Shafts are set at regular distances for maintenance. Structures like bridges, inverted siphons, and tunnels are standard applications. 
Figure 10. Typical cross-section of a Roman aqueduct channel. The channel is built of masonry, and lies in an excavation in the soil. The inside is covered with a red waterproof cement (opus signinum - in red), with characteristic quarter rounds to seal the edges. Carbonate deposits (yellow) are common in some channels.

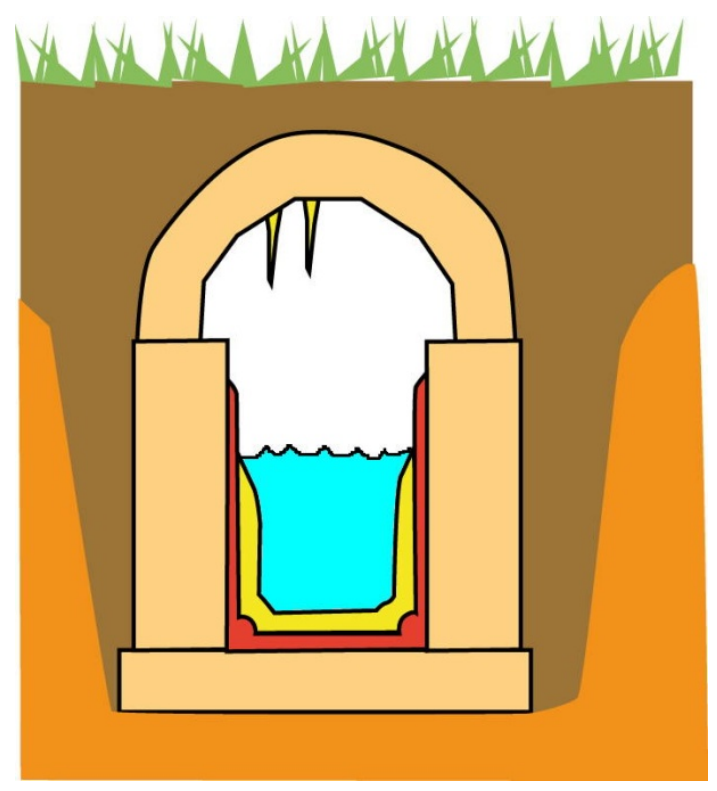

The main feature of Roman aqueducts was a channel that closely followed the contour lines of the land. It was normally built by digging an open excavation in the soil, and by the construction of a masonry channel with vault, which was then covered with soil [50]. Sometimes, the channel was cut in the bedrock [8,50], and covered with slabs. The floor and the sidewalls were covered with a characteristic red waterproof cement, named opus signinum, with a special quarter round structure to strengthen the joint of walls and floor. The channel was usually only half to two-thirds full of water (Figure 10).

Three considerations affected aqueduct construction: The need for a regular slope, the obligation to sometimes cross valleys, and the need to deliver water in the city into a water tower constructed as high as possible, in order to benefit from a high potential energy to distribute the flow in the city. Consequently, inverted siphons and aqueduct bridges were commonly built near cities.

Most aqueduct channels followed contour lines, but valleys were mostly passed by small bridges to avoid damage and contamination by floodwater. Long detours through valleys and around mountains were avoided by the construction of large bridges, inverted siphons and tunnels.

Aqueduct bridges featured semi-circular arches, and were mostly constructed of ashlar masonry or faced concrete. Aqueduct bridges up to three tiers high were used to cross valleys, up to $50 \mathrm{~m}$ deep, while inverted siphon were used for greater depths. Some bridges crossed major rivers, such as the aqueducts of Metz (that crossed the Moselle) and Toulouse (that crossed the Garonne), both in France. Some bridges crossed sea straits, such as the aqueduct in Butrint, Albania, and the Misenum aqueduct, to Nisida, Italy. Most bridges carried a single open channel, but the bridge of the aqueduct of Metz carried a double channel, either for maintenance purposes, or to avoid large lateral stresses from a large-span vault. A striking example of the remains of an aqueduct bridge near city limits can be found in Segovia, Spain (see Figure 11a). The construction of the aqueduct in Segovia was achieved ca. in 
the 1 st century $\mathrm{AD}$. The aqueduct carried water from the Fuente Fria River, situated in the nearby mountains, $17 \mathrm{~km}$ from the city. Just before the entrance in today city center, a monumental $1200 \mathrm{~m}$ long aqueduct bridge is observed. Its maximal height is $35 \mathrm{~m}$ and it is composed of 166 pillars.

Figure 11. (a) Remains of the aqueduct bridge in Segovia; and (b) Remains of the inverted siphon in the Aspendos aqueduct (picture taken from the top of the acropolis).

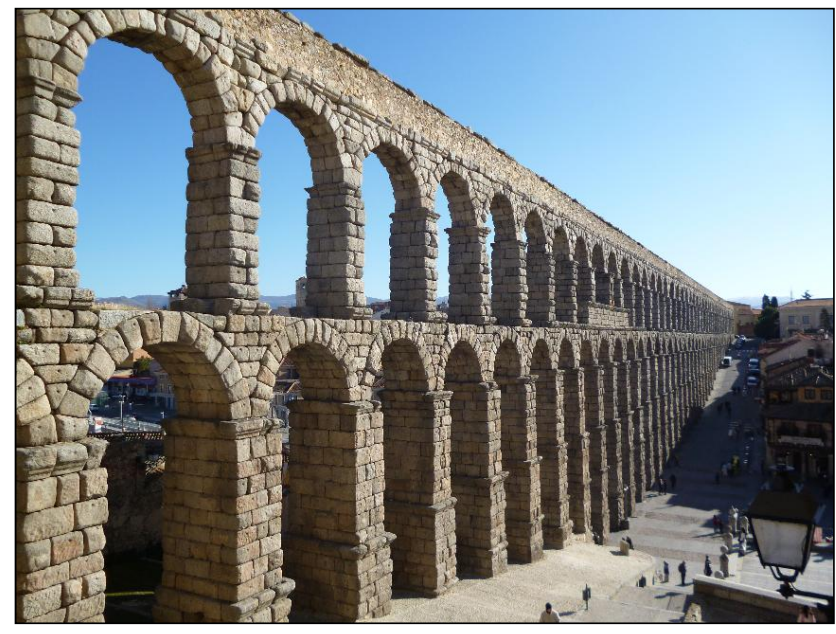

(a)

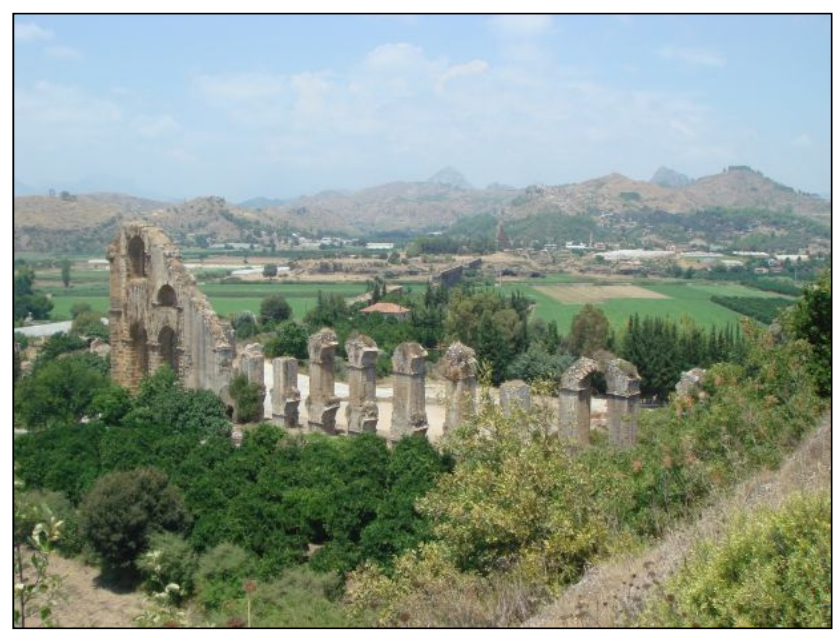

(b)

Inverted siphons are pipes that were operated under pressure. These were mostly constructed using lead pipes in the Western Roman Empire, where lead mining was common (e.g., the aqueducts of Alatri and Termini Imerese in Italy, Toledo and Almuñecar in Spain). In the eastern part of the Empire, stone siphons, constructed from hollowed ashlars of limestone, marble or basalt, were more common (e.g., the aqueducts of Patara and Oinoanda in Hellas, Aspendos and Smyrna in Turkey, Laodicea in Syria, Hippos and Jerusalem in Israel). Terracotta pipes, with thick walls, were also used.

In Aspendos, one of the most spectacular examples of the use of inverted siphons within aqueducts can be observed (see Figures $11 \mathrm{~b}$ and 12). The aqueduct of Aspendos was built in ca. the 3rd century AD. It transported water to the town from a spring located $20 \mathrm{~km}$ to the north of the city [51]. The aqueduct featured a masonry channel with open surface flow following the contour of the land. The $1.5 \mathrm{~km}$ long valley, between the hills and the acropolis, was crossed using a system of three inverted siphons. In this system, water was carried across the valley under pressure in a closed pipeline. This pipeline started from a header tank on the hill and brought the water up to receiving tanks on the two towers, and on the acropolis. The towers arguably served to permit air bubbles to escape, which could otherwise block water flow in the down-going legs of the siphon pipeline. The pipeline consisted of perforated limestone blocks with a $28 \mathrm{~cm}$ central cylindrical hole. The block ends were cut to form socket attachments and a lime-oil sealant was used to cement individual blocks together [54].

An example of a low-pressure siphon is found in the terminal part of the Cadiz aqueduct. Hollowed blocks were used to build a multi-pipe inverted siphon of over $17 \mathrm{~km}$ long at sea level, in order to transport water to elevated tanks in the city. 
Figure 12. Schematic representation of the triple inverted siphon system in the Aspendos aqueduct (lateral view). Drawings inspired by Kessener and Piras [51].

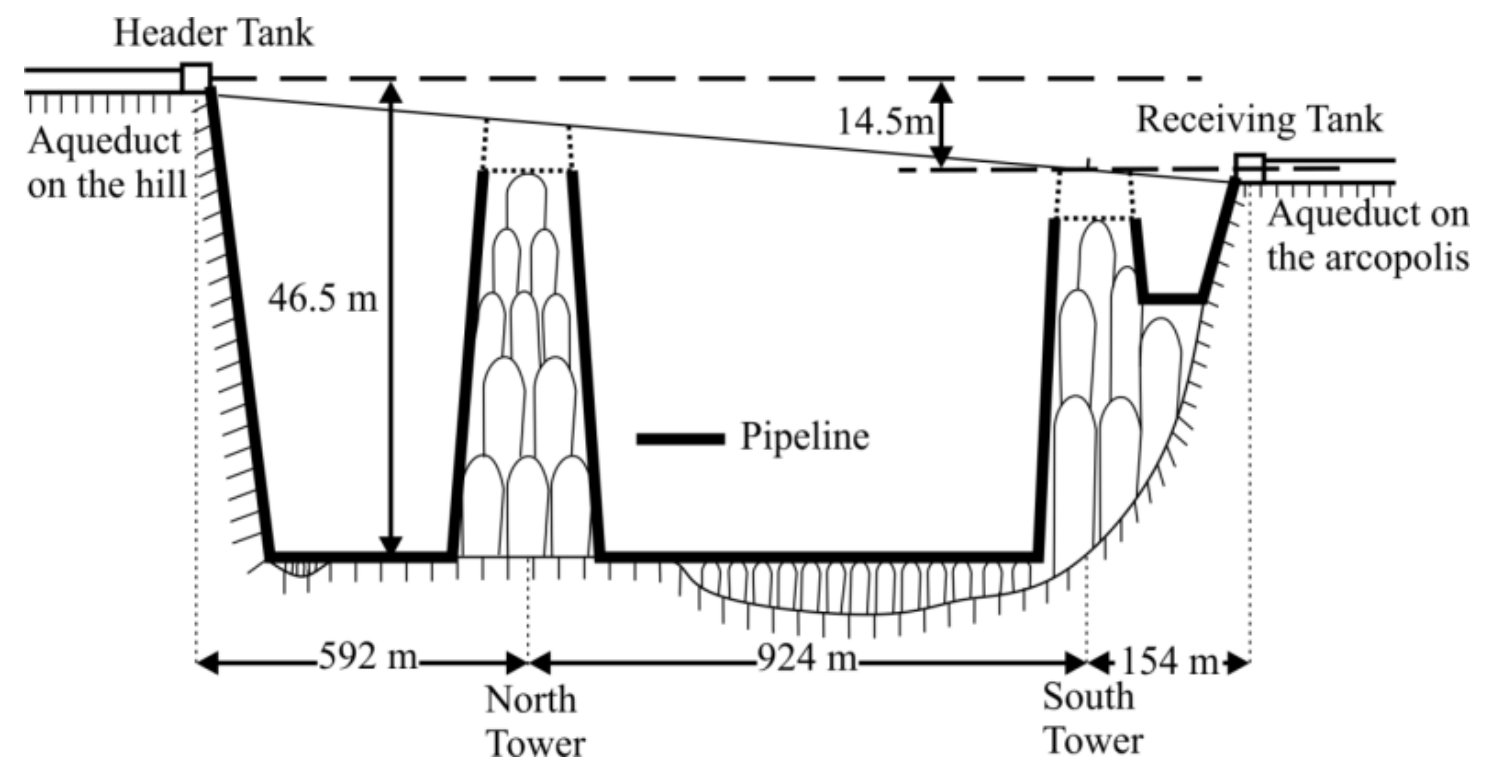

Tunnels were mostly built in a qanat-fashion, connecting vertical shafts dug at regular distances. However, in high mountain areas, long single tunnels were dug from the two sides of the mountain (e.g., the aqueduct of Saldae in Algeria, and the Anio Novus aqueduct in Rome). Steep or instable mountain slopes and vertical rock walls were passed by the excavation of an open gully in the rock, from above (e.g., the aqueducts of Side in Turkey, Cahors and Frejus in France, Chaves in Spain), or by a particularly interesting technique of gallery tunnels, where a qanat-fashion technique was used to construct tunnels parallel to and inside steep rock walls from horizontal shafts (e.g., the aqueducts of Chelva and Cella in Spain, Elaiussa Sebaste in Turkey). The longest tunnel of this type with oblique shafts, built to avoid landslide problems in soft limestone, was built to supply Gadara in Jordan (92 km long).

Aqueducts were also used for transport inside the city limit. In Perge (Turkey), a masonry channel with an open surface flow is observed in the middle of the main colonnaded street (see Figure 13). No covering blocks have been identified. The width of the channel is $1.8 \mathrm{~m}$ and its height is $76 \mathrm{~cm}$. The commencement of several derivations made of terracotta pipes can be observed along the channel length. Water was fed into this channel by a monumental fountain located at the south of the acropolis, at the north end of the main street. In this fountain, water coming from the top of the acropolis was delivered to a large decorative pool through an opening just below a reclining statue. From this pool, water overflowed into the channel built in the middle of the colonnaded street. At approximately every $7 \mathrm{~m}$ in the channel, stone cut obstacles can be observed. Arguably, these obstacles functioned to increase the water height in the channel and to create a cascade structure [55]. This water system was constructed during $c a$. the 2 nd or the 3rd century AD [56,57].

Roman aqueducts are impressive for their length and for their water flow rate. Famous examples are the port-city aqueducts of Carthage (Tunisia, $95 \mathrm{~km}$ long), Phocaea (Turkey, $100 \mathrm{~km}$ long), Cadiz (Spain, 74 km long), Cagliari (Italy, $45 \mathrm{~km}$ long), Cherchell (Algeria, $60 \mathrm{~km}$ long), and Fréjus (France, $42 \mathrm{~km}$ long). Numerous cities were served by several aqueducts (e.g., Lyon and Aix en Provence in France, Cherchell in Algeria, Vienne in France, Jerusalem in Israel, Ephesus in Turkey). Rome, as the 
capital of the Empire, featured some of the most impressive aqueducts. Over the course of 500 years, eleven aqueducts were constructed with total flow rate of $1.13 \times 10^{6} \mathrm{~m}^{3} \mathrm{~d}^{-1}$ and a total length of more than $500 \mathrm{~km}[58]$.

Figure 13. Aqueduct channel in the middle of the main colonnaded street in Perge.

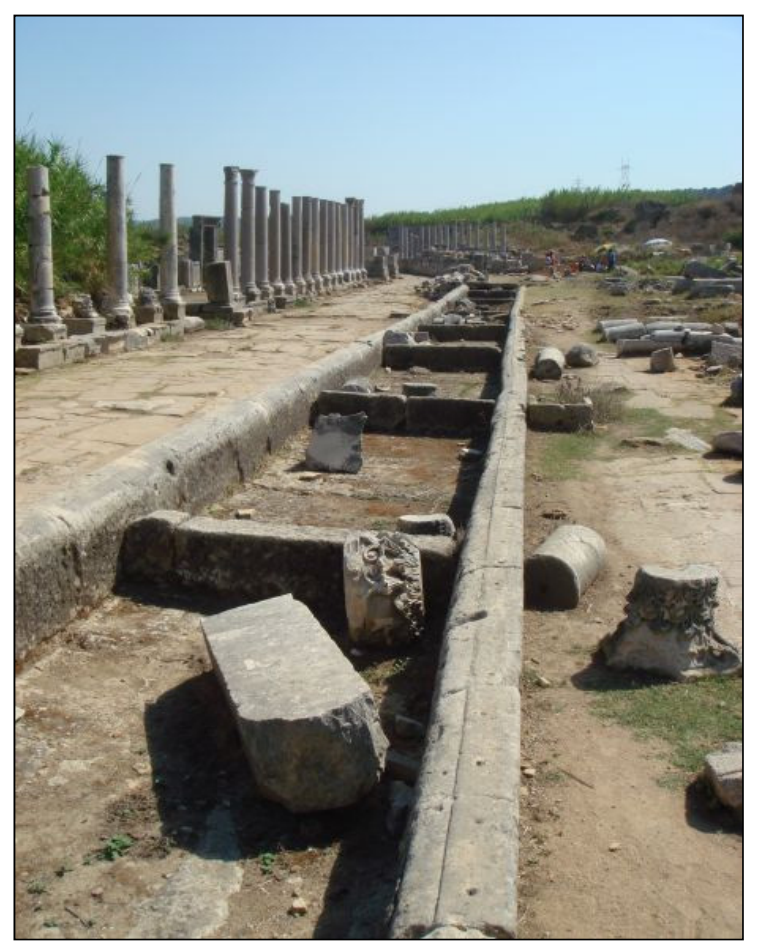

Some aqueducts were fed by more than one source (e.g., the aqueducts of Fréjus in France and Aspendos in Turkey), but nearly all had a single target. A noteworthy exception is the Aqua Augusta or Serino Aqueduct (Figure 14), the longest aqueduct in Southern Italy, in the Province of A vellino [59]. The Serino aqueduct was constructed during the Augustan Age (between 33 and 12 BC), when Marcus Vipsanius Agrippa was curator aquarum in Rome. Arguably, the purpose of the aqueduct was to supply the Roman fleet of Misenum, to supply water for the commercial harbour of Puteoli, and to provide drinking water for several towns [59]. The main channel of the Serino aqueduct was approximately $96 \mathrm{~km}$ long, and included seven main branches to several towns (e.g., Nola, Pompeii, Acerra, Herculaneum, Atella, Pausillipon, Nisida, Puteoli, Cumae, and Baiae) [59]. The Serino aqueduct ended in the Piscina Mirabilis, a large reservoir $72 \mathrm{~m}$ long and $27 \mathrm{~m}$ wide, with a capacity of $12,600 \mathrm{~m}^{3}[60,61]$.

Roman aqueducts consistently illustrate accurate land survey as a prerequisite for aqueducts built with an extremely gentle slope. For instance, large parts of the Nîmes aqueduct (France) were built at a regular slope close to $8 \mathrm{~cm} / \mathrm{km}$ (corresponding to $0.008 \%$ ). Such an impressive realization, even by modern standards, highlights the high skills of the Roman engineers.

Many aqueducts contain carbonate deposits that can be analyzed for relative dating of the period of aqueduct use, to study construction, maintenance and rebuilding techniques, and to determine the amount and quality of the water that was delivered [62]. In many cases, the last deposit indicates a gradual decay of the aqueducts and a collapse of the vaults when maintenance ceased. Carbonate deposits can also be used to determine palaeoclimate conditions in Roman times and, in many cases, 
can give information regarding earthquakes [63]. Characteristics of several Roman aqueducts are referenced in Table 4.

Figure 14. Serino aqueduct in the Campania region of Southern Italy.

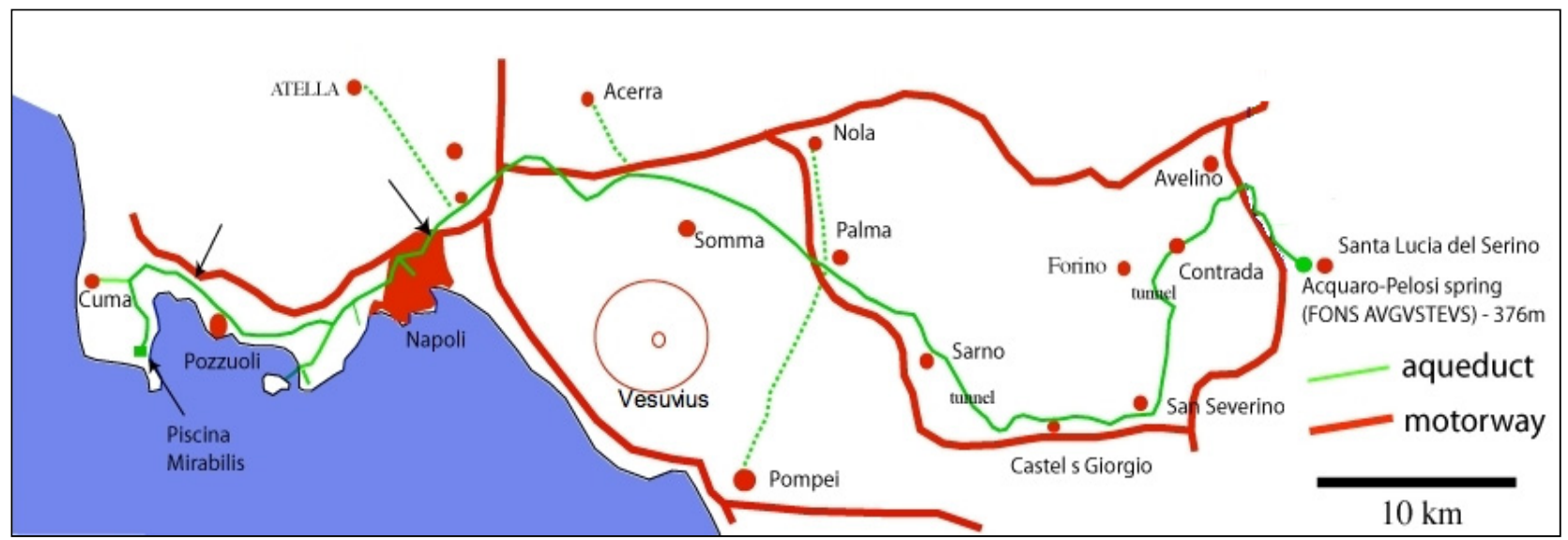

Table 4. Characteristics of a selection of Roman aqueducts (adapted from De Feo et al. [44], Kessener and Piras [51], Chiotis and Marinos [64], Haut and Viviers [65], Ortloff and Crouch [66]).

\begin{tabular}{|c|c|c|c|c|c|}
\hline Aqueduct name & Location & Period & Age of construction & $\begin{array}{c}\text { Length } \\
(\mathbf{k m})\end{array}$ & $\begin{array}{l}\text { Flow rate } \\
\left(\mathrm{m}^{3} \mathbf{d}^{-1}\right)\end{array}$ \\
\hline Cherchell & Algeria & Roman & - & $>45$ & $6,600-40,000$ \\
\hline Cuicul & Algeria & Roman & - & $5-6$ & - \\
\hline Gunugu & Algeria & Roman & - & - & - \\
\hline Arles & France & Roman & 1 st century AD & 48.0 & 8,000 \\
\hline Beaulieu (Aix-en-P.) & France & Roman & - & - & - \\
\hline Brévenne (Lyon) & France & Roman & $1-50 \mathrm{AD}$ & 70.0 & 10,000 \\
\hline Gier (Lyon) & France & Roman & $50 \mathrm{AD}$ & 75.0 & 15,000 \\
\hline Gorze (Metz) & France & Roman & $100-200 \mathrm{AD}$ & 22.3 & - \\
\hline Mons (Fréjus) & France & Roman & $100-200 \mathrm{AD}$ & 39.4 & - \\
\hline Mont d'Or (Lyon) & France & Roman & $40 \mathrm{BC}$ & 26.0 & $2,000-6,000$ \\
\hline Montjeu (Autun) & France & Roman & - & - & - \\
\hline Nîmes & France & Roman & $41-54 \mathrm{AD}$ & $49.8-50.0$ & 35,000 \\
\hline Yzeron-Craponne (Lyon) & France & Roman & $20-10 \mathrm{BC}$ & 40.0 & 13,000 \\
\hline Cologne & Germany & Roman & - & 95.4 & - \\
\hline $\begin{array}{l}\text { Hadrianean (Athens, } \\
\text { tunnel and wells up to } \\
40 \text { m deep ) }\end{array}$ & Hellas & Roman & $125-140 \mathrm{AD}$ & 19.8 & - \\
\hline Chersonisos & Hellas & Roman & $\begin{array}{c}\text { First half of the } 2 \text { nd } \\
\text { century AD }\end{array}$ & 13 & - \\
\hline Corinth (Stymfalia) & Hellas & Roman & $125-160 \mathrm{AD}$ & 85.0 & 80,000 \\
\hline Elyros & Crete, Hellas & Roman & - & 2 & - \\
\hline Gortys & Crete, Hellas & Roman & Late Roman & 15 & - \\
\hline Lyttos & Hellas & Roman & $33 \mathrm{BC}-14 \mathrm{AD}$ & 22 & - \\
\hline
\end{tabular}


Table 4. Cont.

\begin{tabular}{|c|c|c|c|c|c|}
\hline Aqueduct name & Location & Period & Age of construction & $\begin{array}{c}\text { Length } \\
(\mathbf{k m})\end{array}$ & $\begin{array}{c}\text { Flow rate } \\
\left(\mathbf{m}^{3} d^{-1}\right)\end{array}$ \\
\hline Minoa (Chania) & Crete, Hellas & Roman & 2nd century AD & 1.77 & - \\
\hline Moria & Lesvos, Hellas & Roman & $\begin{array}{l}\text { End of } 2 \mathrm{nd} \text { or } \\
\text { beginning of } 3 \mathrm{rd} \\
\text { century AD }\end{array}$ & 26 & - \\
\hline Rhodos (qanat-fashion) & Hellas & Roman & - & - & - \\
\hline Anio Novus (Rome) & Italy & Roman & $52 \mathrm{AD}$ & 86.876 & 189,520 \\
\hline Anio Vetus (Rome) & Italy & Roman & $273 \mathrm{BC}$ & 63.640 & 175,920 \\
\hline $\begin{array}{c}\text { Aqua Alexandrina } \\
\text { (Rome) }\end{array}$ & Italy & Roman & $226 \mathrm{AD}$ & 22.000 & 21,025 \\
\hline Aqua Alsietina (Rome) & Italy & Roman & $2 \mathrm{BC}$ & 32.882 & 15,680 \\
\hline Aqua Appia (Rome) & Italy & Roman & $312 \mathrm{BC}$ & 16.561 & 73,000 \\
\hline Aqua Augusta (Serino) & Italy & Roman & $33-12 \mathrm{BC}$ & 140.0 & 47,520 \\
\hline Aqua Claudia (Rome) & Italy & Roman & $52 \mathrm{AD}$ & 68.977 & 184,280 \\
\hline Aqua Julia (Rome) & Italy & Roman & $33 \mathrm{BC}$ & 22.830 & 48,240 \\
\hline Aqua Marcia (Rome) & Italy & Roman & $144 \mathrm{BC}$ & 91.331 & 187,600 \\
\hline Aqua Tepula (Rome) & Italy & Roman & $127 \mathrm{BC}$ & 17.800 & 17,800 \\
\hline Aqua Trajana (Rome) & Italy & Roman & $109 \mathrm{AD}$ & 58.000 & 113,100 \\
\hline Aqua Virgo (Rome) & Italy & Roman & $19 \mathrm{BC}$ & 20.875 & 100,160 \\
\hline Carthage & Tunisia & Roman & $160 \mathrm{AD}$ & 132.0 & 17,280 \\
\hline Dougga & Tunisia & Roman & - & 12 & - \\
\hline Patara & Turkey & Roman & $100 \mathrm{AD}$ & 25 & - \\
\hline Italica (Trajan) & Spain & Roman & 1st century AD & - & - \\
\hline Apamea & Syria & Roman & 1st century AD & 150 & 43,000 \\
\hline Kaystros (Ephesus) & Turkey & Roman & 2nd century AD & 40 & $9,000-35,000$ \\
\hline Italica (Hadrian) & Spain & Roman & 2nd century AD & - & - \\
\hline Aspendos & Turkey & Roman & 3rd century AD & 20 & 5,600 \\
\hline Valens & Turkey & Roman & 4th century $\mathrm{AD}$ & 250 & - \\
\hline $\begin{array}{l}\text { Athens Roman (built } \\
\text { channel of the aqueduct } \\
\text { near the surface, locally } \\
\text { on waterbridges) }\end{array}$ & Hellas & Roman & $\begin{array}{l}\text { Middle 5th century } \\
\text { AD }\end{array}$ & 21 & \\
\hline
\end{tabular}

\section{Byzantine Period and Middle Ages}

At the beginning of the Byzantine period, the Roman aqueduct tradition was still prevalent. In addition to the repair and the maintenance of pre-existing Roman aqueducts, new aqueducts were built. In Constantinople, during the first centuries of the Byzantine Empire, the longest ancient aqueduct was built [67] to deliver water to the new capital city. It supplied spacious cisterns (e.g., the Basilica cistern). Portions of this aqueduct survive inside of the city walls (Valens Aqueduct; Figure 15). Many other sections remain outside the city, either in ruins or incorporated in the lower portions of the 16th century AD aqueduct of Sinan [67]. 
Figure 15. The Valens Aqueduct of Constantinople (image in the public domain).

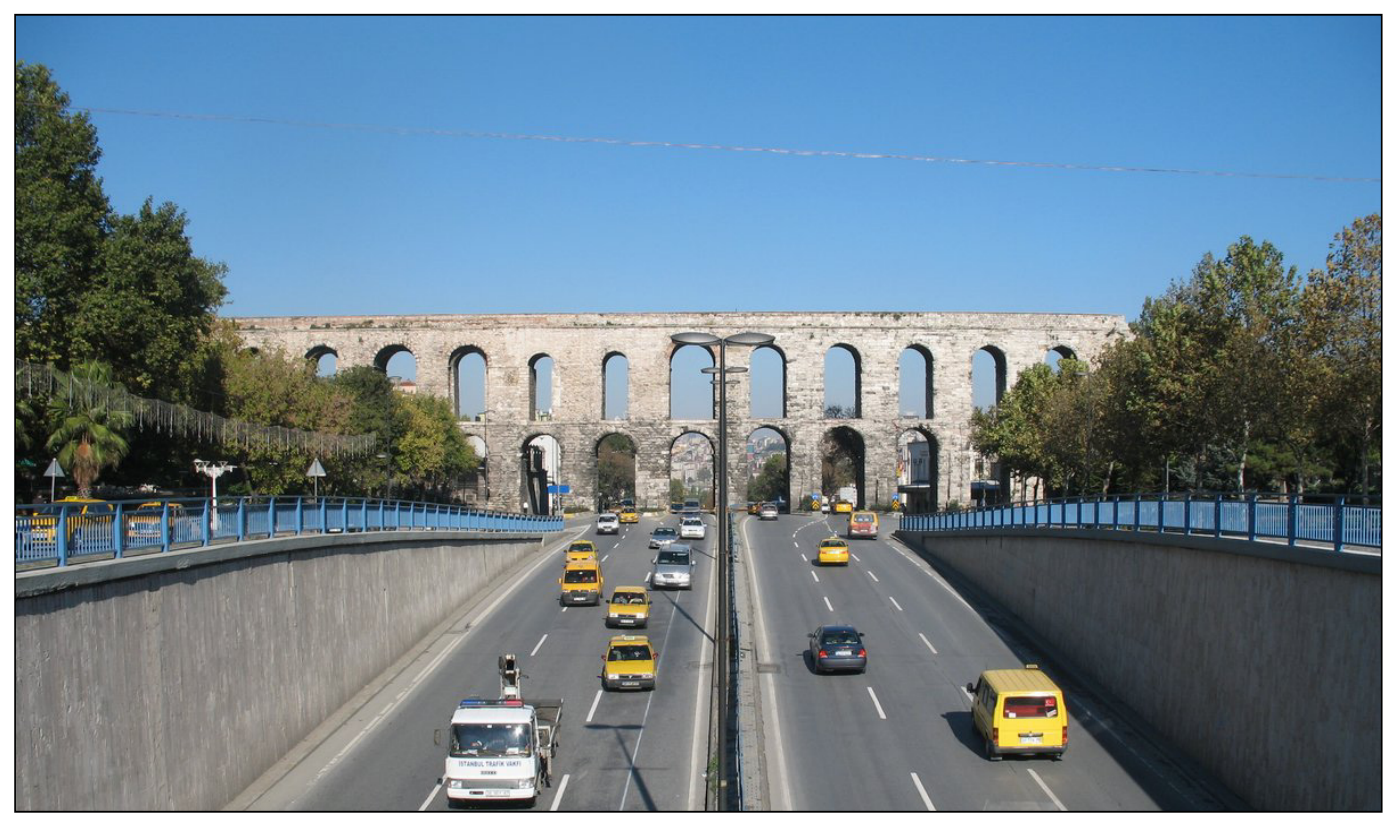

Other Byzantine period aqueduct examples are notable. In Apamea (Syria), at the end of the 5 th century $\mathrm{AD}$, the area of the city where the aqueduct enters the town had been completely reworked [65]. Masonry channels and pipelines were constructed and used until the seventh century AD. This demonstrates that the Byzantine city was not only using a Roman aqueduct, but was also able to build a new water supply system. Parts of the $40 \mathrm{~km}$ long aqueduct of Salamis (Cyprus) are dated to the $c a$. 6th or 7th century $\mathrm{AD}$, being possibly a rebuild of the $c a$. 4th century $\mathrm{AD}$ Late Roman aqueduct. In Selçuk (Turkey), the remains of an aqueduct bridge that belonged to the ancient Selinus aqueduct (delivering water to Ephesus) can be observed. This aqueduct bridge was $656 \mathrm{~m}$ long, with 125 piers and may have been constructed in $c a$. the 6th century AD [68].

Some authors mention that, in the Middle Ages [69], the pre-existing Roman or early Byzantine aqueducts were abandoned in many cities and the inhabitants focused on the construction of cisterns to collect rainwater [69]. For instance, in Smyrna (Izmir, Turkey), well-preserved cisterns (Figure 16) were constructed at the end of the Roman period under the western stoa (columned gallery) of the agora [70,71]. However, as presented below, there are numerous archaeological evidences of the construction of aqueducts during the Middle Ages.

In $c a$. the 11th century $\mathrm{AD}$, at the Daphni monastery near Athens, a Byzantine cistern incorporated a long underground channel collecting and conveying water from a nearby narrow valley, arguably by a qanat-fashion technique. The row of shaft openings can still be observed east of the monastery enclosure. That system assured a safe water supply during periods of siege, since the monastery was a passage fortress, guarding the western entrance of the plain of Athens.

Additional examples from the medieval period are equally notable. In medieval Catalonia (Spain), in $1336 \mathrm{AD}$, the city and lands surrounding Manresa began to suffer from drought. In 1339, the city council decided to construct an aqueduct to bring water from the Llobregat River. The construction of the aqueduct was completed in 1344 [72]. 
Figure 16. Cisterns under Smyrna agora.

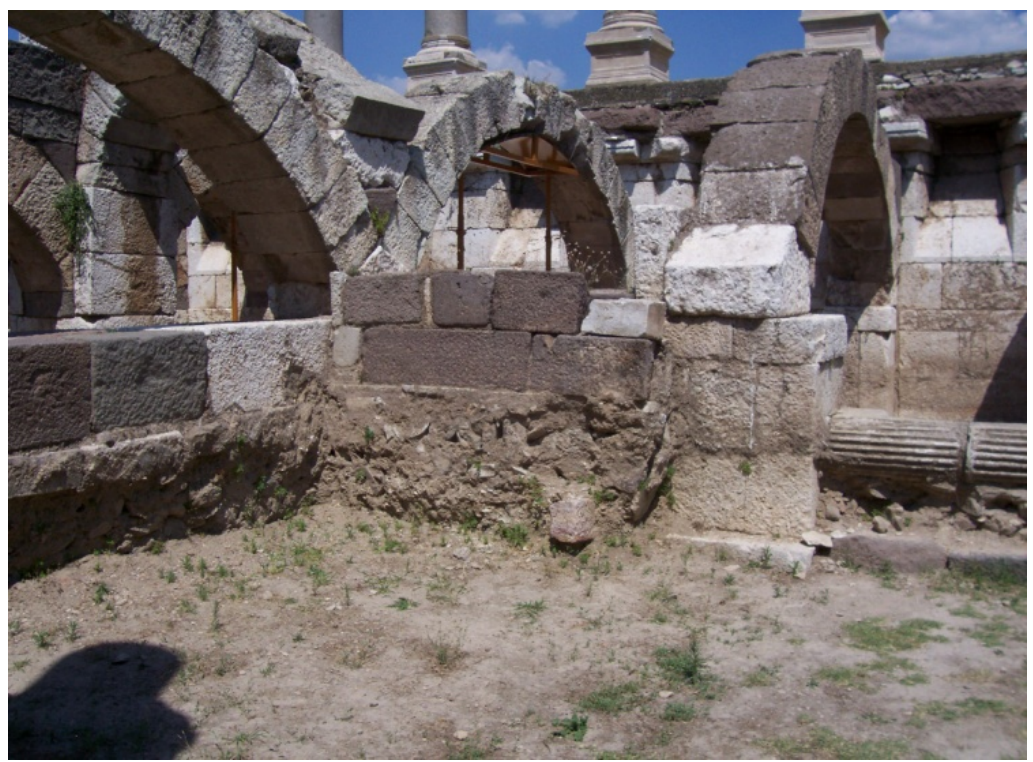

In the late Middle Ages, the city of Siena, in Central Italy, had a high population density and had to face the problem of supplying water within the city walls for domestic use, crafts, economic and commercial activities, as well as for fire fighting. A network of underground channels, named Bottini, was built, achieving a total length of about $25 \mathrm{~km}$ in the late $c a$. 14th century AD. The Bottini have been capturing and conducting rain water from the countryside to fountains in the city center for centuries [73].

Remains of other medieval aqueducts can be observed elsewhere in Italy. One of these remains is in the city of Sulmona, in the Abruzzo region of Central Italy. The medieval aqueduct of Sulmona was built in $1256 \mathrm{AD}$, under the reign of Manfred, son of Frederick II of Swabia. The remains of the aqueduct bridge consist of 21 pointed arches, with a total length of about $100 \mathrm{~m}$. The aqueducts of Sulmona supplied mills and workshops, but also orchards and gardens within the city walls. The medieval aqueduct of Gubbio (Condotto in Italian, i.e., conduit), in the Umbria region of Central Italy, served as a hydraulic connection between a dam named Bottaccione and a fortified area located upstream of the Palazzo Ducale (named Cassero), with an approximate length of $2 \mathrm{~km}$. It was constructed near the end of $c a$. the 14th century AD to supply the highest part of the city. In the city of Perugia, in Umbria, the construction of an aqueduct from Mount Pacciano to the Piazza Grande (now Piazza IV Novembre) began in 1254 AD with a length of about $3 \mathrm{~km}$. The Fontana Maggiore, located between the Duomo and the Palazzo dei Priori, was the terminus of the aqueduct. Finally, the remains of a medieval aqueduct can be observed in Salerno, in the Campania region of Southern Italy. The medieval aqueduct of Salerno was built by the Lombards in $c a$. the 7th century AD. It was later restored by the Normans in $c a$. the 9th century AD to supply water to the monastery of Saint Benedict. Its structure consists of two main branches. Its length was approximately $650 \mathrm{~m}$, including $255 \mathrm{~m}$ where two tiers of pointed arches were supported by massive pillars of masonry, with a maximum height of about $21 \mathrm{~m}$. The remaining length is about one hundred meters.

In Cyprus, in the 15th century AD, a medieval sugarcane mill at Kolossi was powered by a ground-level aqueduct channel delivering water from the foothills of the Trodos Mountains (Figure 17). 
Figure 17. Aqueduct supplying the cane mill at Kolossi, Cyprus.

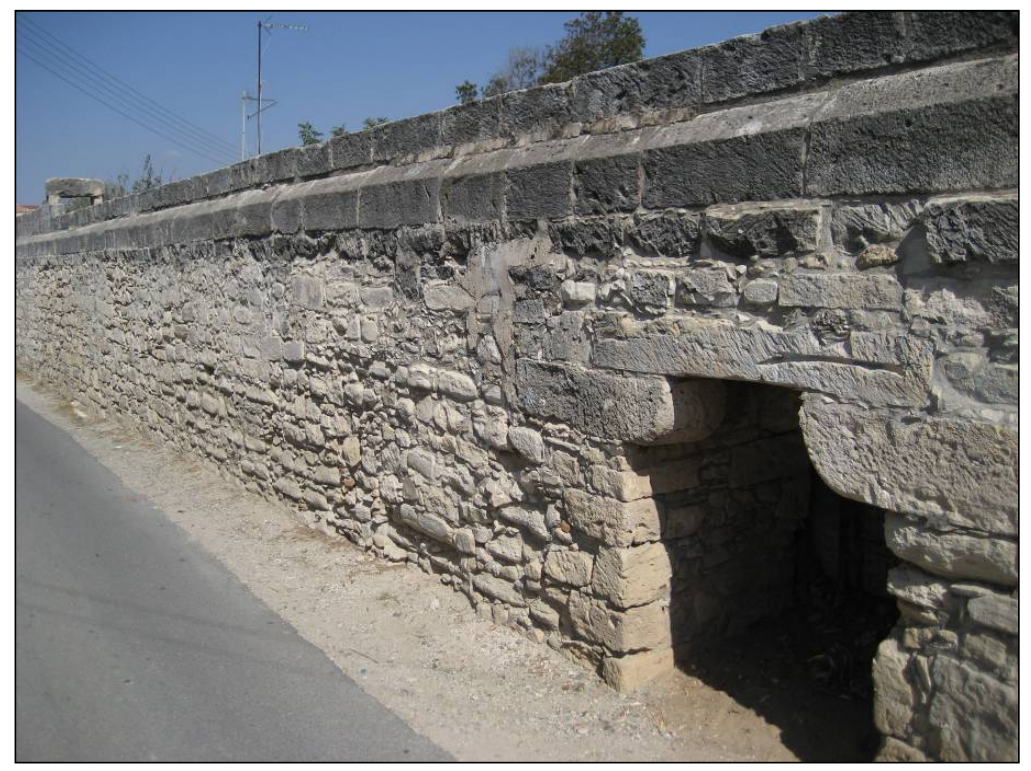

\section{Ottoman and Byzantines Periods}

The emergence of the Ottoman Turkish tribe from western Turkey and their conquest of the Balkans occurred from the middle of the $c a$. 14th century AD. The urban infrastructure of many former Byzantine cities was enriched with various constructions necessary for basic needs, such as: (a) religious buildings (e.g., mosques); (b) secular buildings (of social-public character and for domestic use, including commercial buildings); and (c) military architecture (e.g., fortifications and towers) $[74,75]$.

Water was an important issue for religious practice. Turkish baths and fountains flourished near the mosques, with a high demand for water. Therefore, the consolidation of the Ottoman domination in the Balkans region, combined with their increasing skills in relevant techniques, led to the construction of numerous water supply projects throughout Western Asia Minor and the Balkans, dating from the middle of $c a$. the 15 th to the 17th century AD [76,77]. Numerous examples of aqueduct works during Ottoman period can still be observed (e.g., at Istanbul, Bursa, Edirne and Smyrna in Turkey; Pylos, Kos, Kavala and Feres in Hellas; Skopje in the modern Yugoslav Republic of Macedonia) [77-82]. The Alexander aqueduct in Smyrna and a tunnel of the Pylos aqueduct are shown in Figure 18a,b, respectively. These various remains, as well as descriptions found in written sources testify not only to similarities between these constructions but also their adaptation to the ground. Many of the aqueducts were in use until the beginning of the 20th century and incorporate techniques of repairs and improvements, which aimed to maintain their operation.

Water was usually transported to the towns from springs several kilometres away, e.g., more than $12 \mathrm{~km}$ away in Pylos [78], and $30 \mathrm{~km}$ away in Chalcis (Hellas) [41,42]. The task was accomplished either by using parts of earlier aqueducts (e.g., the Istanbul aqueduct) [67], or by erecting new ones. Already exploited springs and new springs cumulatively increased the amount of available water [78,79]. The charitable actions of prosperous local or regional governors resulted in the construction of several aqueducts. The majority of these constructions exhibit technical expertise and incorporate structural, architectural and functional provisions clearly corresponding to the large 
Ottoman water supply works of Istanbul dating to $c a$. the 16th century $\mathrm{AD}$, which incorporated technical knowledge of Roman and Byzantine aqueducts [67].

Figure 18. Ottoman period aqueducts: (a) The Alexander aqueduct in Smyrna, (picture by Frédéric Boissonnas, end of the 19th century); and (b) tunnel of the Pylos aqueduct.

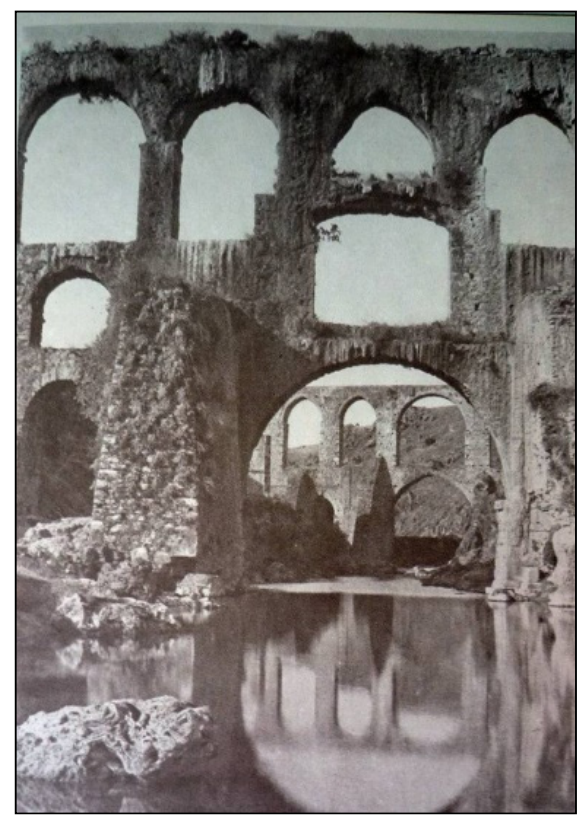

(a)

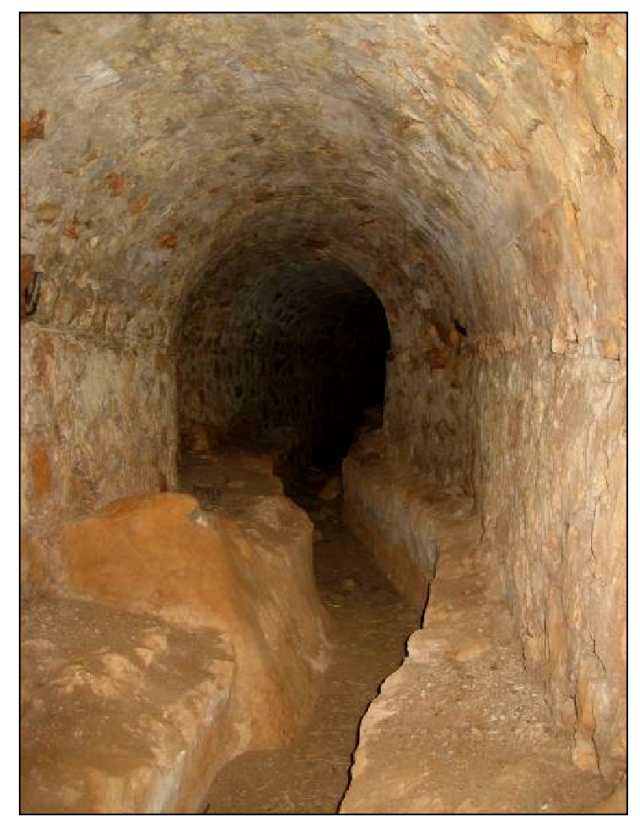

(b)

Ottoman aqueducts are characterized by numerous arched bridges, which often combine pointed and regular arches in the same branch. The use of metal and wooden tensile strengthening elements is quite common and many traces of covered and underground conduits survive today. Unfortunately, original water capture structures are rarely observed.

Several Ottoman officials were associated with the construction and operation of the aqueducts [67]. In addition, the maintenance and the repair of an aqueduct exempted those who performed this work, whether Muslim or Christian, from taxation [77,83].

In addition to aqueducts, other technologies were also employed by the Byzantines. For example, in Phyllida, in Eastern Macedonia, more than 18 qanats, of 35 to $4000 \mathrm{~m}$ long, are described by Vavliakis [84]. These hydraulic works were used for the water supply of villages and monasteries since $c a$. the 18th century AD, and most of them are still in operation today [85]. The others suffered from destruction by floods and earthquakes, clogging of tunnels by branches of trees or shrub roots, deposition of calcium carbonate, etc. [86].

\section{Discussion and Conclusions}

Knowledge about the building of urban aqueducts existed in Hellas from early Minoan times onward ( $c$ a. 3000 BC). The strong technological base of the Minoan Era has been the basis of advanced aqueduct technological progress during the centuries that followed. During the Classical and Hellenistic periods, urban city planning and aqueduct technology moved through various stages of sophistication by implementing different design philosophies. The evolution of the designed city is 
reflected in the scale of the projects, which resulted in water adequacy and more widespread hygienic water use. Obviously, the scale of modern cities exceeds those of antiquity. This is also reflected in the scale of water infrastructures. As a result, a direct comparison is not possible. During the Roman period, the scale of aqueduct projects was highly increased as the Roman engineers learned how to effectively use concrete. Frontinus once asked if anyone "will ... compare the idle Pyramids, or those other useless though much renowned works of the Hellenes, with these aqueducts, with these indispensable structures?". Pliny remarked that "if one takes careful account of the abundant supply of water for public purposes, for baths, pools, channels, houses, gardens, suburban villas; the length of the aqueduct courses - the high arches, mountains tunnelled, valleys crossed - he will confess that there has never been a greater marvel in the whole world." [87].

The technological improvements of each era fulfilled the demands of society for the extended use of water. Many civilizations, which were great centers of power and culture, were built in areas that could not support the populations that developed there [88]. Several centuries after the Roman Empire, the importance of water in the Muslim religion triggered the reintroduction of long aqueducts during the Ottoman period. Peaceful periods also contributed to the improvement of aqueduct construction, which extended outside the secure domain of fortified areas.

The meaning of sustainability should be re-evaluated in the light of ancient public works and management practices. Technological developments based on sound engineering principles can extend the usable life of aqueducts. The use of small-scale infrastructures, parallel to large-scale ones, greatly assists sustainability and resiliency. The principles and practices of sustainable water use should not be forgotten even during periods of water adequacy. Safety and security of a water supply in emergency situations, including turbulent periods, should be kept in mind in our designs of urban water aqueducts.

\section{Acknowledgments}

The authors wish to thank Meisha Hunter for her English revision to the text.

\section{Conflicts of Interest}

The authors declare no conflict of interest.

\section{References}

1. Yang, K. Re-discussion on the design of Chang An in West Han Dynasty. Archaeology 1989, 4, 348-356.

2. Koutsoyiannis, D.; Angelakis, A.N. Hydrologic and Hydraulic Sciences and Technologies in Ancient Greek Times. In The Encyclopedia of Water Sciences; Stewart, B.A., Howell, M., Eds.; Marcel Dekker Inc: New York, NY, USA, 2003; pp. 415-418.

3. Tamburrino, A. Water Technology in Ancient Mesopotamia. In Ancient Water Technologies; Mays, L.W., Ed.; Springer: Dordrecht, The Netherland, 2010; pp. 29-51.

4. Viollet, P.L. Water Management in the Early Bronze Age Civilization. In Proceedings of La Ingenieria Y La Gestion Del Agua a Traves de Los Tiempos, Alicante, Spain, 30 May-1 June 2006. 
5. Angelakis, A.N.; Savvakis, Y.M.; Charalampakis, G. Aqueducts during the Minoan Era. Water Sci. Technol. Water Supply 2007, 7, 95-102.

6. Angelakis, A.N.; Spyridakis, S.V. Major urban water and wastewater systems in Minoan Crete, Greece. Water Sci. Technol. Water Supply 2013, 13, 564-573.

7. Nriagu, J. Environmental pollution and human health in ancient times. Encycl. Environ. Health 2011, 489-506.

8. Mays, L.W. Water Technology in Ancient Egypt. In Ancient Water Technologies; Mays, L.W., Ed.; Springer: Dordrecht, The Netherland, 2010; pp. 53-65.

9. Franco, L. Ancient Mediterranean harbours: A heritage to preserve. Ocean Coast. Manag. 1996, 30, 115-151.

10. Viollet, P.L. L'hydraulique dans les civilisations anciennes (Hydraulics in ancient civilizations). Presse de l'Ecole des Ponts et Chaussées: Paris, France, 2000.

11. Lightfoot, D. Survey of Infiltration Karez in Northern Iraq: History and Current Status of Underground Aqueducts; UNESCO, Report IQ/2009/SC/RP/1; United Nations Educational, Scientific and Cultural Organization (UNESCO): Paris, France, 2009.

12. Stiros, S.C. Accurate measurements with primitive instruments: The "paradox" in the qanat design. J. Archaeol. Sci. 2006, 33, 1058-1064.

13. Wulff, H.E. The qanats of Iran. Sci. Am. 1968, 4, 94-105.

14. Sun, Q.; Tao, W.; Kobori, I.; Liang, L. Case Study V: Karez in the Turpan Region of China. In Seeing Traditional Technologies in a New Light Using Traditional Approaches for Water Management in Drylands; Bigas, H., Adeel, Z., Schuster, B., Eds.; United Nations Educational, Scientific and Cultural Organization: Paris, France, 2009.

15. George, R.L. The history of plumbing. Plumb. Eng. 2001, 3, 45-53.

16. Jansen, M. Water supply and sewage disposal at Mohenjo-Daro. World Archaeol. 1989, 21, 177-192.

17. Wright, R.P.; Bryson, R.A.; Schuldenrein, J. Water supply and history: Harappa and the Beas regional survey. Antiquity 2008, 82, 37-48.

18. Neary, D.G.; Ice, G.G.; Rhett, J.C. Linkages between forest soils and water quality and quantity. For. Ecol. Manag. 2009, 258, 2269-2281.

19. Beach, T.; Luzzadder-Beach, S.; Dunning, N.; Cook, D. Human and natural impacts on fluvial and karst depressions of the Maya Lowlands. Geomorphology 2008, 101, 308-331.

20. Kirk, F.D.; Duffy, C.J. Prehispanic water pressure: A new world first. J. Archaeol. Sci. 2010, 37, 1027-1032.

21. Grossman, J.W. Human-landscape interactions. Encycl. Archaeol. 2008, 1458-1476.

22. Alvarado, G.E.; Soto, G.J. Volcanoes in the pre-Columbian life, legend, and archaeology of Costa Rica (Central America). J. Volcanol. Geotherm. Res. 2008, 176, 356-362.

23. Reyes-Knoche, A. Sustainable Water Supply_-The Case of Pre-Columbian Peru. In Proceedings of the International Water Association (IWA) Specialized Conference on Water \& Wastewater Technologies in Ancient Civilizations, Istanbul, Turkey, 22-24 March 2012.

24. Reyes-Knoche, A. Water Supply and Sanitation in Ancient Peru: Pre-Columbian Cultures and the Incas. In Proceedings of the International Water Association (IWA) Specialized Conference on Water \& Wastewater Technologies in Ancient Civilizations; Bari, Italy, 28-30 May 2009.

25. Fairley, J.P., Jr. Geologic water storage in Precolumbian Peru. Lat. Am. Antiq. 2003, 14, 193-206. 
26. Yuan, Y.H. An Outline History of Hydraulic Engineering History of China. China Press of Hydraulic Engineering \& Hydraulic Power: Beijing, China, 1986.

27. Zheng, X.Y. Water management in a city of southwest China before the 17 th Century. Water Sci. Technol. 2013, 13, 574-581.

28. Wittenberg, H.; Schachner, A. The ponds of Hattuša-Early groundwater management in the Hittite Kingdom. Water Sci. Technol. 2013, 13, 692-698.

29. Öziş, U. Historical dams in Turkey; National Committee of International Commission on Large Dams: Ankara, Turkey, 1999.

30. Ozkaldi, A.; Huseyin, A.; Koksal, B.C. Evaluation of historical water works in Turkey from hydraulic engineering point of view. In Proceedings of the International History Seminar on Irrigation and Drainage, Tehran, Iran, 2-5 May 2007.

31. Garbrecht, G. Hydrologic and Hydraulic Concepts in Antiquity. In Hydraulics and Hydraulic Research: A Historical Review; Garbrecht, G., Ed.; Balkema Publisher: Rotterdam, The Netherlands, 1987; pp. 1-22.

32. Fahlbusch, H. Water in human life: Technical innovations in hydraulic engineering in the last 5000 years. ICID J. 2000, 49, 1-16.

33. Belli, O. Urartian Irrigation Canals in Eastern Anatolia. Archeology and Art Press: Istanbul, Turkey, 1997.

34. Wessels, J.; Hoogeveen, R.J.A. Renovation of Qanats in Syria. In Sustainable Management of Marginal Drylands, Application of indigenous knowledge for coastal drylands, Proceedings of A Joint United Nations University (UNU) - United Nations Educational, Scientific and Cultural Organization (UNESCO)-International Center for Agricultural Research in the Dry Areas (ICARDA) International Workshop, Alexandria, Egypt, 21-25 September 2002.

35. Caponetti, L. Gallerie drenanti e sistemi idraulici Etruschi. Il caso di Tuscania. In I Patrimoni di Comunità in Italia fra Storia e Cultura, Natura e Territorio, Proceedings of I Patrimoni di Comunità in Italia fra Storia e Cultura, Natura e Territorio, Parco Naturale del Bosco delle Sorti della Partecipazione di Trino (VC), Italy, 16-18 December 2005.

36. Angelakis, A.N.; de Feo, G.; Laureano, P.; Zourou, A. Minoan and Etruscan hydro-technologies. Water 2013, 5, 972-987.

37. Martini, P.; Drusiani, R. History of the Water Supply of Rome as a Paradigm of Water Services Development in Italy. In Evolution of Water Supply Through the Millennia; Angelakis, A.N., Mays, L.W., Koutsoyiannis, D., Mamassis, N., Eds.; IWA Publishing: London, UK, 2012; pp.444-466.

38. Bambini, R.; Campagnoli, A.; Campagnoli, M.; Cappa, G. Un acquedotto etrusco-romano nel territorio di Cerveteri. Opera Ipogea 2007, 9, 95-104.

39. Koutsoyiannis, D.; Zarkadoulas, N.; Angelakis, A.N.; Tchobanoglous, G. Urban water management in Ancient Greece: Legacies and lessons. ASCE J. Water Resour. Plan. Manag. 2008, 134, 45-54.

40. Zarkadoulas, N.; Koutsoyiannis, D.; Manassis, N.; Angelakis, A.N. A Brief History of Urban Water Management in Ancient Greece. In Evolution of Water Supply through the Millennia; Angelakis, A.N., Mays, L.W., Koutsoyiannis, D., Mamassis, N., Eds.; IWA Publishing: London, UK, 2012; Chapter 10, pp. 259-270. 
41. Bakhuizen, S.C. Studies in the Topography of Chalcis on Euboea-A Discussion of the Sources. Brill Academic Publishers: Leiden, The Netherlands, 1985.

42. Kiel, M. The Turkish Aqueduct of Chalkis. A Note on the Date of Construction and the Identity of Its Founder. In Studies in the Topography of Chalcis on Euboea; Bakhuizen, S.C., Kiel, M., Eds.; E.J. Brill: Leiden, The Nederlands, 1985.

43. Garbrecht, J.D.; Garbrecht, G.K.H. Water Supply Challenges and Solutions of the Ancient City of Pergamon. In Proceedings of Oklahoma Water Conference 2005, Stillwater, OK, USA, 27-28 September, 2005.

44. De Feo, G.; Laurano, P.; Mays, L.W.; Angelakis, A.N. Contribution of the Greek and Roman Civilizations to the Evolution of Water Supply. In Evolution of Water Supply through the Millennia; Angelakis, A.N., Mays, L.W., Koutsoyiannis, D., Mamassis, N., Eds.; IWA Publishing: London, UK, 2012; Chapter 14, pp. 351-382.

45. Bellwald, U.; Al-Huneidi, M.; Salihi, A.; Keller, D.; Naser, R.; Al-Eisawi, D. The Petra Siq, Nabataean Hydrology Uncovered. Petra National Trust: Amman, Jordan, 2003.

46. Mouton, M.; Al-Dbiyat, M. Stratégies d'acquisition de l'eau et société au moyen orient depuis l'antiquité; Institut français du Proche Orient: Beyrouth, Lebanon, 2009.

47. Tsuk, T. Water at the End of the Tunnel: Touring Israel's Ancient Water System (in Hebrew); Yad Izhak Ben-Zvi Publications: Jerusalem, Israel, 2013.

48. ROMAQ Database Homepage. Available online: http://www.romaq.org (accessed on 25 November 2013).

49. Bailhache, M. L'évolution du débit des aqueducs gallo-romains (Evolution of the flow rate of Roman aqueducts). Doss. Archéol. 1979, 38, 19-49.

50. Hodge, A.T. Roman Aqueducts and Water Supply, 2nd ed.; Duckwort: London, UK, 2008.

51. Kessener, P.; Piras, S. The pressure line of the Aspendos aqueduct. Adalya II 1998; pp. 159-187. Available online: http://www.romanaqueducts.info/aquapub/kessener1998a.pdf (accessed on 25 November 2013).

52. Matias, R.R. La Mineria Aurifera Romana del Nordoeste de Hispania: Ingenieria Minera $Y$ Gestion de las Explotaciones Auriferas Romanas en la Sierra del Teleno (Leon, Espana). In Proceedings of the III Congreso de las Obras Públicas Romanas, Astorga, Spain, 5-7 October 2006.

53. Wikander, O. Handbook of Ancient Water Technology; Brill Academic Publishers: Leiden, The Netherlands, 2000; p. 471.

54. Ortloff, C.R. Computational fluid dynamics investigation of the hydraulic behaviour of the Roman inverted siphon system at Aspendos, Turkey. J. Archaeol. Sci. 2003, 30, 417-428.

55. Haut, B.; Viviers, D. Water Supply in the Middle East During Roman and Byzantine Periods. In Evolution of Water Supply through the Millennia; Angelakis, A.N., Mays, L.W., Koutsoyiannis, D., Mamassis, N., Eds.; IWA Publishing: London, UK, 2012; Chapter 13, pp.319-350.

56. Abbasoglu, H. Perge. Curr. World Archaeol. 2010, 41, 28.

57. Tunçer, M. Perge Conservation Plan Report; Perge Conservation Plan Research Report; Akman Project Co: Perge, Turkey, 1992. 
58. De Feo, G.; Mays, L.W.; Angelakis, A.N. Water and Wastewater Management Technologies in the Ancient Greek and Roman Civilizations. In Treatise on Water Science; Wilderer, P., Ed.; Academic Press: Oxford, UK, 2011; Volume 4, pp. 3-22.

59. De Feo, G.; Napoli, R.M.A. Historical development of the Augustan aqueduct in Southern Italy: Twenty centuries of works from Serino to Naples. Water Sci. Technol. 2007, 7, 131-138.

60. De Feo, G.; De Gisi, S.; Malvano, C.; De Biase, O. The greatest water reservoirs in the ancient Roman world and the "Piscina Mirabilis" in Misenum. Water Sci. Technol. 2010, 10, 350-358.

61. De Feo, G.; Laureano, P.; Drusiani, R.; Angelakis, A.N. Water and wastewater management technologies through the centuries. Water Sci. Technol. 2010, 10, 337-349.

62. Surmelihindi, G.; Passchier, C.W.; Spötl, C.; Kessener, P.; Bestmann, M.; Jacob, D.E.; Baykan, O.N. Laminated carbonate deposits in Roman aqueducts: Origin, processes and implications. Sedimentology 2013, 60, 961-982.

63. Passchier, C.W.; Wiplinger, G.; Güngör, T.; Kessener, P.; Sürmelihindi, G. Evidence for major displacement on a normal fault in Western Turkey dislocating a Roman aqueduct. Terra Nova 2013, (in press).

64. Chiotis, E.D.; Marinos, G.P. Geological aspects on the sustainability of ancient aqueducts of Athens. Bull. Geol. Soc. Greece 2012, 46, 16-38.

65. Haut, B.; Viviers, D. Analysis of the water supply system of the city of Apamea, using Computational Fluid Dynamics. Hydraulic system in the north-eastern area of the city, in the Byzantine period. J. Archaeol. Sci. 2007, 34, 415-427.

66. Ortloff, C.R.; Crouch, P.D. The urban water supply and distribution system of the Ionian city of Ephesos. J. Archaeol. Sci. 2001, 28, 843-860.

67. Çeçen, K. Roma Su Yollarının En Uzunu; Türkiye Sınai Kalkınma Bankası: İstanbul, Turkey, 1996.

68. Hodge, A.T. Roman Aqueducts and Water Supply, 2nd ed.; Duckwort: London, UK, 2008.

69. Wiplinger, G. The Aqueducts of Ephesos. Available online: http://www.oeai.at/index.php/watersupply.html (accessed on 11 August 2011).

70. Viollet, P.L. Aqueducts: A short history. J. Hydraul. Res. 2003, 20, 26-27.

71. Lancaster, L.C. Early Examples of So-Called Pitched Brick Barrel Vaulting in Roman Greece and Asia Minor: A Question of Origin and Intention. In Proceedings of Bautechnik imantiken und vorantiken kleinasien, An Internationale Konferenz, Istanbul, Turkey, 13-16 June 2007.

72. Levi, E.A. The Agora of İzmir and Cultural Tourism; The International Committee for Documentation of Cultural Heritage (CIPA): Antalya, Turkey, 2003.

73. Garceau, M.E. "I call the people." Church bells in fourteenth-century Catalunya. J. Mediev. Hist. 2011, 37, 197-214.

74. Rugania, B.; Pulselli, R.M.; Niccolucci, V.; Bastianoni, S. Environmental performance of a XIV century water management system: An emergy evaluation of cultural heritage. Resour. Conserv. Recycl. 2011, 56, 117-125.

75. Kanetaki, E. Ottoman Baths in Greece: A Contribution to the Study of Their History and Architecture. In Bathing Culture of Anatolian Civilizations: Architecture, History, and Imagination; Ergin, N., Ed.; Peeters Publishing: Leuven, Belgium, 2011; pp. 221-255. 
76. Kanetaki, E. Architectural and Technical Aspects Regarding the Construction of Hammams in Ottoman Greece. In Proceedings of 2nd International Conference Balneorient, Thermae, Hammam, Damascus, Syria, 2012.

77. Kiel, M. Yenice-i Vardar: A Forgotten Turkish Cultural Centre in Macedonia of the 15th \& 16th Century. In Studia Byzantina et Neohellenica Neerlandica 3; E.J. Brill: Leiden, The Netherlands, 1971; pp. 300-329.

78. Lowry, H. The Shaping of Ottoman Balkans, 1350-1500. B.U.P.: Istanbul, Turkey, 2008.

79. Antoniou, G.P. The Architecture and Evolution of the Aqueduct of Pylos-Navarino. In Proceedings of IWA Specialized Conference on Water \& Wastewater Technologies in Ancient Civilizations, Istanbul, Turkey, 22-24 March 2012.

80. Antoniou, G.P. Ottoman Aqueducts in the Helladic Region-Architecture and Construction. In Proceedings of Comité International des Études Pré-Ottomanes et Ottomanes (CIEPO 20), Rethymnon, Greece, 27 June-1 July 2012.

81. Benet, J. The Fortress of Avarin I-Cedid. In A Historical and Economic Geography of Ottoman Greece, Hesperia Supplements 34; Zarinebaf, F., Ed.; American School of Classical Studies at Athens: Princenton, NJ, USA, 2005; pp. 241-265.

82. Kiel, M. Remarks on Some Ottoman-Turkish Aqueducts and Water Supply Systems in the Balkans-Kavalla, Chalkis, Levkas and Ferai/Ferecik. In De turcicis aliisque rebus: Commentarii Henry Hofman dedicati; Boeschoten, H., Ed.; Instituut voor Oosterse Talen en Culturen: Utrecht, The Netherlands, 1992; pp. 105-139.

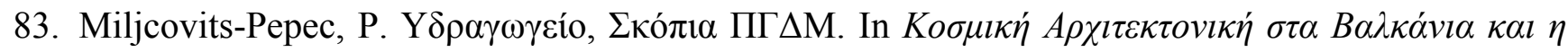
$\triangle \iota \alpha \tau \eta \dot{\rho} \eta \sigma \dot{\eta} \tau \eta \varsigma ;$ Historical Manuscripts Commission (HMC): Thessaloniki, Greece, 1997; pp. 342-343.

84. Kiel, M. Ottoman Building Activity along the Via Egnatia. In The Via Egnatia Under Ottoman Rule 1380-1699: Halcyon Days in Crete II; Zachariadou, E., Ed.; Crete University Press: Rethymnon, Greece, 1996; pp. 155.

85. Vavliakis, E. The Qanat systems in Greece: A study of Qanat Systems in Phyllida of Seeres from Morphological, Hydrographic and Socio-Economical View; Aristotle University of Thessaloniki: Thessaloniki, Greece, 1989.

86. Voudouris, K.; Christodoulakos, Y.; Stiakakis, M.; Angelakis, A.N. Hydrogeological characteristics of Hellenic aqueducts like qanats. Water 2013, 5, 1326-1345.

87. Pliny the Elder. Natural History, Volume X, Books 36-37, 2nd ed.; Harvard University Press: Harvard, UK, 1962.

88. Blumenstein, O.; Weingartner, H.; Vavelidis, M. Qanats between Menikion and Pangeon Mountains: A Forgotten and Endangered Resource for Local Water Supply. In Proceedings of XIX Congress of the Carpathian Balkan Geological Association, Thessaloniki, Greece, 23-26 September 2010; pp. 23-29.

(C) 2013 by the authors; licensee MDPI, Basel, Switzerland. This article is an open access article distributed under the terms and conditions of the Creative Commons Attribution license (http://creativecommons.org/licenses/by/3.0/). 